\title{
Marika Pirveli
}

\section{Koncepcja morfoznaku z kodem obrazowym i semantycznym w badaniach nad tożsamością transgranicznego miasta na przykładzie Cedyni}

\begin{abstract}
Artykuł o tożsamości transgranicznego miasta i jego mieszkańców ma charakter teoretyczno-empiryczny. Analizowany materiał stanowi nieznaczną część badań wykonanych na potrzeby projektu rewitalizacji. Autorka, podzielając tezę o wzajemnym oddziaływaniu struktur przestrzennych i społecznych, osią treści uczyniła założenie, że bez topofilii genius loci jest pojęciem pustym. Tekst składa się z sześciu części. Pierwsza w nich to wprowadzenie zawierające wyjaśnienie najistotniejszych terminów, następnie szczegółowo przedstawiono obszar badań, tkankę urbanistyczną oraz definicję i wzór morfoznaku. W ostatnich częściach przedstawiono wyniki konsultacji społecznych oraz podsumowanie.
\end{abstract}

Słowa kluczowe: tkanka urbanistyczna, lokalna społeczność, Cedynia, prawo do miasta, morfoznak.

\section{Wprowadzenie}

Autorka podziela tezę o wzajemnym oddziaływaniu struktur przestrzennych i struktur społecznych. Każde ludzkie działanie odzwierciedla się w przestrzeni (Rykiel, Pirveli 2005). Przestrzeń miejska, przedmiot badań morfologii formy urbanistycznej jest kategorią trójwymiarową (Conzen 1960, Koter 1974). Wymiar horyzontalny tworzą układy przestrzenne, wymiar wertykalny - budowle. Trzeci wymiar wypełnia przestrzeń między wymiarami horyzontalnym i wertykalnym i zarazem je kształtuje oraz jest pod ich wpływem - to procesy społeczne, tj. procesy wyróżnione z ogółu zjawisk i przeciwstawione zjawiskom przyrodniczym właśnie ze względu na to, że zjawiska przyrodnicze w przeciwieństwie do społecznych istnieją niezależnie od działań ludzkich (Znaniecki 1912, 1919, 1938). Koncepcja morfoznaku, opisana szczegółowo w innym miejscu (Pirveli 2011), ukazuje podejście do badań o trójwymiarowej (3D) przestrzeni miejskiej. Wyrasta ona z urbomorfologii (morphology urban) (Larkham 1991, s. 51) i komunikacyjnej teorii kultury (Hall 1959) oraz jest osadzona w „nauce o mieście” (Urban studies... UiO). 
Utożsamianie się ludzi z miejscem zamieszkania jest postrzegane w tekście jako zakorzenienie. Zakorzenienie człowieka $\mathrm{z}$ miejscem ukazuje $\mathrm{w}$ istocie utożsamianie się z żywą kulturą miasta ${ }^{1}$ jako podstawą budowania tożsamości i pamięci zbiorowej. Żywa kultura - źródło i skutek procesów społecznych - to wielowymiarowe środowisko życia jednostek i grup społecznych oraz funkcjonowania instytucji społecznych, w którym zachodzą dynamiczne procesy, rozwijają się praktyki kulturowe, powstają mniej lub bardziej trwałe rezultaty (materialne i niematerialne wytwory) praktyk. Zarówno jednostki, grupy, instytucje, procesy, praktyki, jak i ich wytwory charakteryzują się zróżnicowanym, najczęściej wielowarstwowym i zmiennym nacechowaniem aksjologicznym oraz zróżnicowanymi, zmiennymi i wielowarstwowymi, najczęściej polisemicznymi, znaczeniami. Artefaktom przestrzennym (przedmiotom, zdarzeniom będącym sztucznym wytworem, nieistniejącym w naturze) znaczenie nadają zatem ludzie, poprzez swój do nich stosunek. Artefakt jako „duch miejsca jest kategorią obiektywną, a przynajmniej intersubiektywną. [...] Jest korelatem kultury symbolicznej i normatywnej" (Rykiel, Pirveli 2009, s. 177-178). Żeby miejsce bogate $\mathrm{w}$ artefakty z dalekiej i bliskiej przeszłości stało się miejscem znaczącym, ludzie powinni odczuwać w stosunku do nich topofilię.

Topofilia - subiektywna i aksjologiczna relacja człowieka z jego otoczeniem - wypełnia miejsce duchem, ukazując stosunek osoby do miejsca, które w ten sposób nabiera wartości emocjonalnej (Rykiel, Pirveli 2009, s. 178). Bez topofilii fragmenty przestrzeni ze śladami kultury materialnej stają się martwą naturą. Stosunek (topofilia) mieszkańców do miejsca (genius loci) wynika w istocie nie tylko ze znajomości historii i zasiedziałości, ale i z relacji członków lokalnej społeczności między sobą, które zachodzą w tym miejscu jako praktyki społeczne (np. sąsiedzkie). Powstaje w ten sposób tkanka miasta (tissu urbain), rozumiana według $H$. Lefebvre (2009) jako stanowiąca o formie, funkcji i strukturze miasta. Koncepcja morfoznaku z kodem obrazowym i semantycznym opisuje podejście i buduje narzędzie do badań (Pirveli 2011), którego celem jest poznawanie, rozumienie i syntetyzowanie treści o fizycznej (lub

${ }^{1}$ Żywa kultura - pojęcie zapożyczone z kulturoznawstwa. Termin ten w literaturze specjalistycznej pojawił się w latach 30. minionego stulecia (Benedict 1966, s. 60 i 118). Pojęcie zostało ponownie odkryte, zredefiniowane i przystosowane do badań nad kulturą miejsca (miasta/wsi) w 2012 r. przez kulturoznawcę z Uniwersytetu Warszawskiego Barbarę Fatygę. 
zbudowanej) tkance miasta ${ }^{2}$ (kod obrazowy) oraz o ludziach i procesach ją kształtujących (kod semantyczny).

Zrozumieć ludzkie wartości, rozwój i interakcje, jakie społeczność i jego otoczenie fizyczne - Cedynia i cedynianie - nawiązują ze sobą, oznacza poznawanie wpływu cedyńskiej architektoniczno-urbanistycznej tkanki miasta kształtowanej co najmniej od X w. na wysiłki lokalnej społeczności i lokalnej społeczności na architekturę miejsca na rzecz rozwoju miasta i społeczności. Jest to ważne dla procesu rewitalizacji Cedyni, której celem jest niwelowanie problemów społecznych, aktywizacja społeczności lokalnej, nowa, lepsza jakość życia dla mieszkańców, którzy stali się użytkownikami XI-wiecznej cedyńskiej przestrzeni 72 lata temu i mają ,prawo do miasta”; ,prawo do zmiany i wynajdywania miasta na nowo takim, jakim go [pragną ...]. Wynajdywanie miasta na nowo w sposób nieunikniony zależy od sprawowania kolektywnej, zespołowej władzy nad procesami urbanizacji” (Harvey 2012, s. 22). „Prawo do miasta” mają mieszkańcy zorganizowani jako społeczność bądź zbiorowość terytorialna - tj. cedyńska Gemeinschaft bądź Gesellschaft ${ }^{3}$. „Żądanie prawa do miasta [...] oznacza żądanie pewnego rodzaju władzy nad kształtowaniem procesów urbanizacyjnych, nad sposobami, w jakie nasze miasta są tworzone i przekształcane, i zrobienie tego w fundamentalny i radykalny sposób" (Harvey 2012, s. 23). Miasto Cedynia również ma swoje prawa. Peter Marcuse, profesor planowania miejskiego na Uniwersytecie Columbia (Nowy Jork), interpretuje pojęcie „prawa do miasta" w artykule Prawa w miastach a prawo do miasta (Marcuse 2013). Podkreśla znaczącą różnicę dzielącą te dwa pojęcia. Jest to zarówno strate-

${ }^{2}$ Tkanka miejska - pojęcie zapożyczone z urbanistyki - to cała kompozycja zabudowy, składająca się z mniejszych elementów, tj. budynków, ulic, placów, dziedzińców itd., które razem tworzą substancję miasta. W urbanistyce oznacza ona regularną strukturę zabudowy, charakterystyczną dla przestrzeni miejskiej, czyli równomierną, gęstą i zwartą. Zabudowa tego typu regulowana jest przez kształtowaną sieć ulic i placów oraz przestrzeń dziedzińców otoczoną budynkami (patrz: Kiernikiewicz-Wieczorkiewicz 1997, s. 37). Pojęcie „tkanka miejska” (tissu urbain) wprowadził do teorii urbanistycznej francuski filozof Henri Lefebvre w 1968 r. (Lefebvre 2009), który opisując sztuczne przeszczepianie ustalonych a priori struktur miejskich, twierdził, że w ten sposób narzuca się mieszkańcom także miejski styl życia.

${ }^{3}$ Gemeinschaft - rodzaj stosunków społecznych oparty przede wszystkim na ,woli organicznej”, głównie na emocjach. Łączy jednostki, rozumiane jako pełne osobowości, na podstawie bliskości emocjonalnej i ogarnia całe ich życie. Gesellschaft - rodzaj stosunków społecznych o charakterze formalnorzeczowym, opartych na ,woli arbitralnej”, na racjonalnej kalkulacji, umowie i wymianie (regulowanych przez formalne prawo). Łączy jednostki jedynie w aspekcie wykonywania przez nie określonych ról społecznych (Tönnies 1988, s. 21-23). 
giczna, jak i polityczna różnica, która wyznacza horyzont ambicji i dążeń oraz pokazuje charakter ruchów wdrażających ją w życie. Jakby nie interpretować praw do miasta (cedynian do Cedyni), oznaczają one udział mieszkańców w realizacji polityki miejskiej odpowiadającej ich potrzebom, ale również w nowej, ogólnodostępnej przestrzeni publicznej, w której mogliby prowadzić swą działalność. Wieki temu budowana Cedynia i obecnie odnawiane budynki, drogi czy place mogą okazać się bezwartościowe, jeśli nie będą uwzględnione potrzeby mieszkańców, którzy powinni utożsamiać się z rewitalizowanymi miejscami.

Poznawanie opinii mieszkańców gminy i miasta Cedynia na temat tego, co powinno być $\mathrm{w}$ mieście rewitalizowane, było celem badań sondażowych i wielu spotkań warsztatowych organizowanych w Cedyni w pierwszej połowie $2017 \mathrm{r}$. Przedstawione w tekście dociekania nad tożsamością transgranicznej Cedyni to analiza materiałów pozyskanych w ramach przeprowadzonych tam studiów na potrzeby projektu „Partycypacyjne programowanie procesu rewitalizacji Gminy Cedynia na lata 2014-20120”, którego częścią była diagnoza społeczna.

\section{Cedynia - lokalizacja w czasie i w przestrzeni}

Cedynia jest nazwą małego zachodniopomorskiego miasteczka (1587 os., stan: 31.12.2016 r.) położonego na kilku morenowych wzgórzach, w zachodniej części Pojezierza Myśliborskiego, w odległości ok. $90 \mathrm{~km}$ na południe od Szczecina i ok. $60 \mathrm{~km}$ na wschód od Berlina. Miasto leży na skraju Wzgórz Krzymowskich, zwanych też Karpatami Cedyńskimi, stanowiących dawne zbocze doliny Odry przepływającej jeszcze do XIX w. u podnóża miasta. W latach 1820-1860 przeprowadzono prace przy regulacji Odry, które odsunęły rzekę ku zachodowi o blisko $3 \mathrm{~km}$, a na żyznych terenach powstały tzw. Żuławy Cedyńskie (ok. -0,3 m p.p.m.).

Cedynia jest centralnym ośrodkiem osadniczym i usługowo-handlowym rolniczo-leśnej gminy o tej samej nazwie, w której użytki rolne stanowią $40 \%$, lasy i grunty leśne $-42 \%$, wody $-5 \%$, drogi, koleje, tereny zabudowane, tereny różne - 4\%, nieużytki - 8\% (Studium... 2017, s. 15). Jednym z najważniejszych wyznaczników położenia geograficznego gminy jest dolina Odry, stanowiąca jej zachodnią granicę. Podstawowy układ drogowy Cedyni wykształcił się ok. X w. na schemacie dróg prowadzących do przeprawy rzecznej na Odrze, która rozwidlała się na dwa główne trakty: południowo-wschodni (ob. DW125 - przebiega przez plac Wolności, ulicę Chrobrego i szosę moryńską w kierunku Bielinka i Morynia) oraz północno-wschodni (ob. DW124 - przebiega wzdłuż ulicy 
Mieszka I i szosy chojeńskiej w kierunku przejścia granicznego w Osinowie Dolnym i dalej do niemieckiego Bad Freienwalde).

$\mathrm{W}$ widłach wspomnianych traktów powstało najpierw grodzisko (ryc. 1), a następnie miasteczko z wytyczonym regularnym rynkiem (ryc. 2). Po południowej stronie grodziska, na stoku wzgórza znajdowało się cmentarzysko.

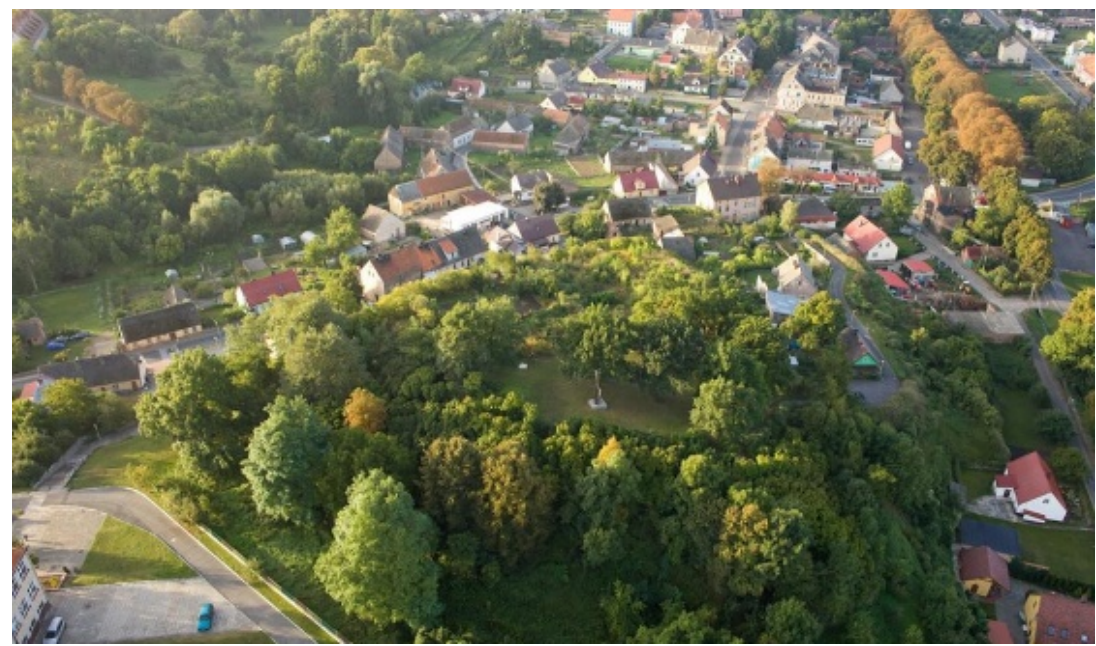

Ryc. 1. Widok na grodzisko z drona. Dokumentacja przygotowana w ramach „Polsko-niemieckich warsztatów pt. Nowoczesne metody w archeologii” (16-20.09.2013) Źródło: Serwis Nauka w Polsce: www.naukawpolsce.pap.pl

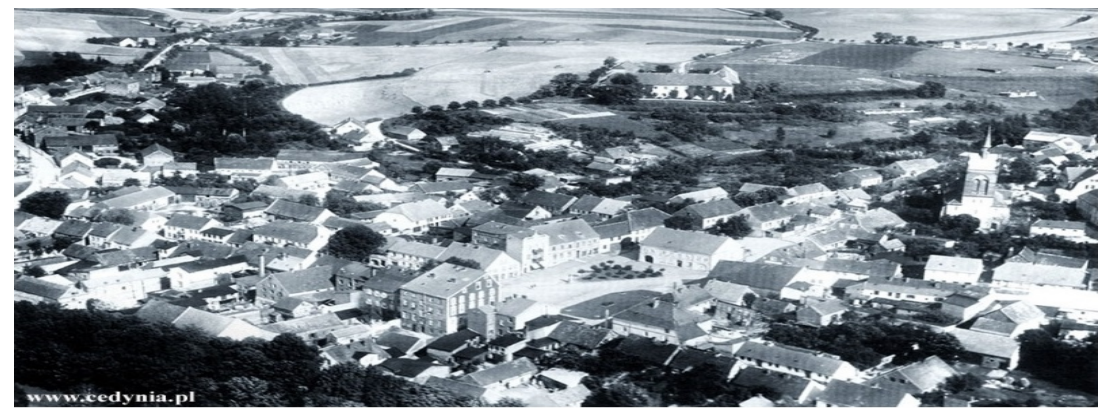

Ryc. 2. Cedynia. Widok na miasteczko z pochylonym rynkiem, wyraźnie widocznym w postaci trapezoidalnego placu powstałego w X w. (ob. pl. Wolności. Stan: początek XX w.) Źródło: cedynia.pl

Miasto było świadkiem wielu wojen, starć mocarstw i zmian politycznych. W czasie zmieniała się również nazwa miasta, która po łacinie brzmi Ceden, a po niemiecku - Zehden. W przeszłości Cedynię nazywano Cidinia, Cedno 
(Dzwonkowski 1918, Kociuba 2012), Cedzyna i Szczerbiec (Białecki 2002, s. 38). Pod obecną nazwą Cedynia jest znana od 12 listopada 1946 r. (Rozporządzenie Ministrów... 1946, s. 8).

W gminie jest 229 stanowisk archeologicznych (ze starożytności - 100 stanowisk, z epoki kamienia - 37, z epoki brązu - 93, z okresu rzymskiego - 17, z wczesnego średniowiecza - 78, średniowiecza - 69 stanowisk), w tym 63 w Cedyni (Studium.... 2017, s. 40). Danych na ich temat dostarcza „Studium krajobrazu kulturowego z pradziejów, wczesnego średniowiecza i średniowiecza w obszarze gminy Cedynia - wytyczne archeologiczne" (Korzeń 2009, s. 28). Cedyńskie stanowiska archeologiczne są objęte trzema rodzajami stref archeologicznej ochrony konserwatorskiej - WI (2 stanowiska), WII (14 stanowisk) i WIII (47 stanowisk) ${ }^{4}$.

W Cedyni pełną ochroną archeologiczno-konserwatorską (strefa WI) objęte są dwa stanowiska: Osada i grodzisko wczesnośredniowieczne (AZP:41-02/13) oraz Osada kultury łużyckiej i klasztor średniowieczny (AZP:41-02/6). Osada kultury łużyckiej (VII-VI w. p.n.e.) i grodzisko wczesnośredniowieczne (IX-X w.) znajdują się na wzniesieniu Góry Czcibora (ryc. 3). Jest to miejsce pamięci historycznej; odwołuje się do dorobku pierwszych Piastów i odnosi się do bitwy pod Cedynią. Na początku XXI w. trwał dysput naukowy na temat poprawnego lokalizowania bitwy stoczonej przez Mieszka I pod Cedynią. Pojawiły się publikacje, które kwestionowały taką lokalizację, podejrzewając w niej akt polityczny rządów komunistycznych PRL (Zaremba 2005, Migdalski 2007, Brzostek 2009, s. 57-86, Polniak 2011). Cedynianie wiedzą o tej dyskusji chociażby na podstawie informacji na stronie Muzeum Regionalnego w Cedyni (patrz: MRwC dla turystów). Niezależnie od tego - kolokwialnie mówiąc - jak daleko może posunąć się władza komunistyczna, dążąc do osiągania swojego celu oraz co, gdzie i jak się działo w X w., w świadomości obecnych mieszkańców Cedyni grodzisko i miejsce bitwy pod Cedynią są aktem i artefaktem dumy i prawie jedyną przyczyną utożsamiania Cedyni z polskością.

${ }^{4}$ WI - pełna ochrona archeologiczno-konserwatorska, wykluczająca wszelką działalność inwestycyjną i inną; strefa ta obejmuje stanowiska wpisane do rejestru zabytków i ujęte w ewidencji służby ochrony zabytków. WII - częściowa ochrona konserwatorska stanowisk archeologicznych, dopuszczająca inwestowanie pod określonymi warunkami; strefy te obejmują stanowiska ujęte w ewidencji służby ochrony. WIII - ograniczona ochrona konserwatorska stanowisk archeologicznych, gdzie obowiązuje prowadzenie interwencyjnych badań archeologicznych w przypadku podejmowania prac ziemnych; strefy te obejmują stanowiska ujęte w ewidencji służby ochrony zabytków (Studium .... 2017, s. 40-44, tab. 7-11). 


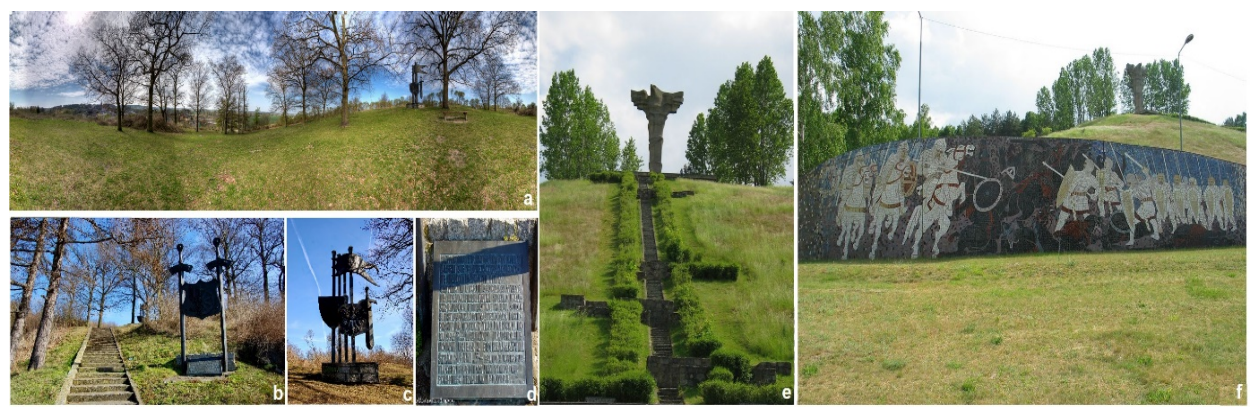

Ryc. 3. Grodzisko (a, b, c, d) i Góra Czcibora (e, f) - genius loci Cedyni: a - widok na grodzisko, $\mathrm{b}$ - metalowy pomnik przy wejściu na grodzisko $\mathrm{z}$ tablicą informacyjną, c - metalowy pomnik w centrum grodziska, przedstawiający cztery włócznie i miecze,

na których znajdują się dwie tarcze $\mathrm{z}$ orłem piastowskim, d - tablica pamiątkowa, e - miejsce upamiętniające zwycięską bitwę księcia Mieszka I z margrabią Hodonem stoczoną 24 czerwca 972 r. i 15-metrowy pomnik przedstawiający stylizowanego orła wzbijającego się do lotu; do pomnika prowadzą liczące 270 stopni kamienne schody, f - mozaika przedstawiająca scenę walki Piastów nad wojskami Marchii Łużyckiej; w tym miejscu corocznie w okolicach 24 czerwca odbywa się inscenizacja bitwy pod Cedynią - pokazy walk średniowiecznych w wykonaniu bractw rycerskich (stan: 2017 r.)

Źródło: cedynia.pl

Ulokowany na skarpie odrzańskiej gród miał położenie obronne i strzegł szlaku przyodrzańskiego (ryc. 2). Z późniejszego okresu rzymskiego osadnictwo koncentrowało się oprócz grodu na południowych krańcach dzisiejszego miasta (Wołągiewicz 1960). W IX i X w. gród należał do plemienia Licikowiczów i nadzorował zachodnie krańce ich ziem. Za panowania Mieszka I, gród z podgrodziem rozbudowano i wzmocniono. Dostęp do wnętrza grodu umożliwiała budowla bramna, usytuowana po północno-wschodniej stronie umocnień (Rajman 2009, s. 9). Z tym grodem identyfikowana jest lokalizacja bitwy stoczonej o ujście Odry w 972 r., w której uczestniczyli Mieszko I i jego brat Czcibor oraz margrabia Marchii Łużyckiej Hodon (Olejnik 1998). Po grodzisku pozostały dziś tylko ślady w postaci górującego nad miastem wzniesienia o rozmiarach ok. 100 x $120 \mathrm{~m}$. W XIX w. wzgórze od strony miasta zostało częściowo zniszczone i zniwelowane. W 1985 r. przy wejściu na grodzisko ustawiono metalowy pomnik, z dwoma mieczami wbitymi w grunt, między którymi znajduje się tarcza $\mathrm{z}$ herbem miasta oraz u stóp tablica informacyjna $\mathrm{z}$ brązu $\mathrm{z}$ napisem: „w dniu św. Jana Chrzciciela starli się w miejscowości zwanej Cedynią...". 


\section{Elementy przestrzenne w świetle rysu historycznego}

Najważniejszym impulsem dla rozwoju dzisiejszej Cedyni było powstanie ok. 1260 r. na jej terenie klasztoru Cysterek, pełniącego obecnie funkcję hotelu (ryc. 4). W tym czasie dokonano lokacji osady, bez nadawania jej praw miejskich, które otrzymała w 1299 r. $^{5}$
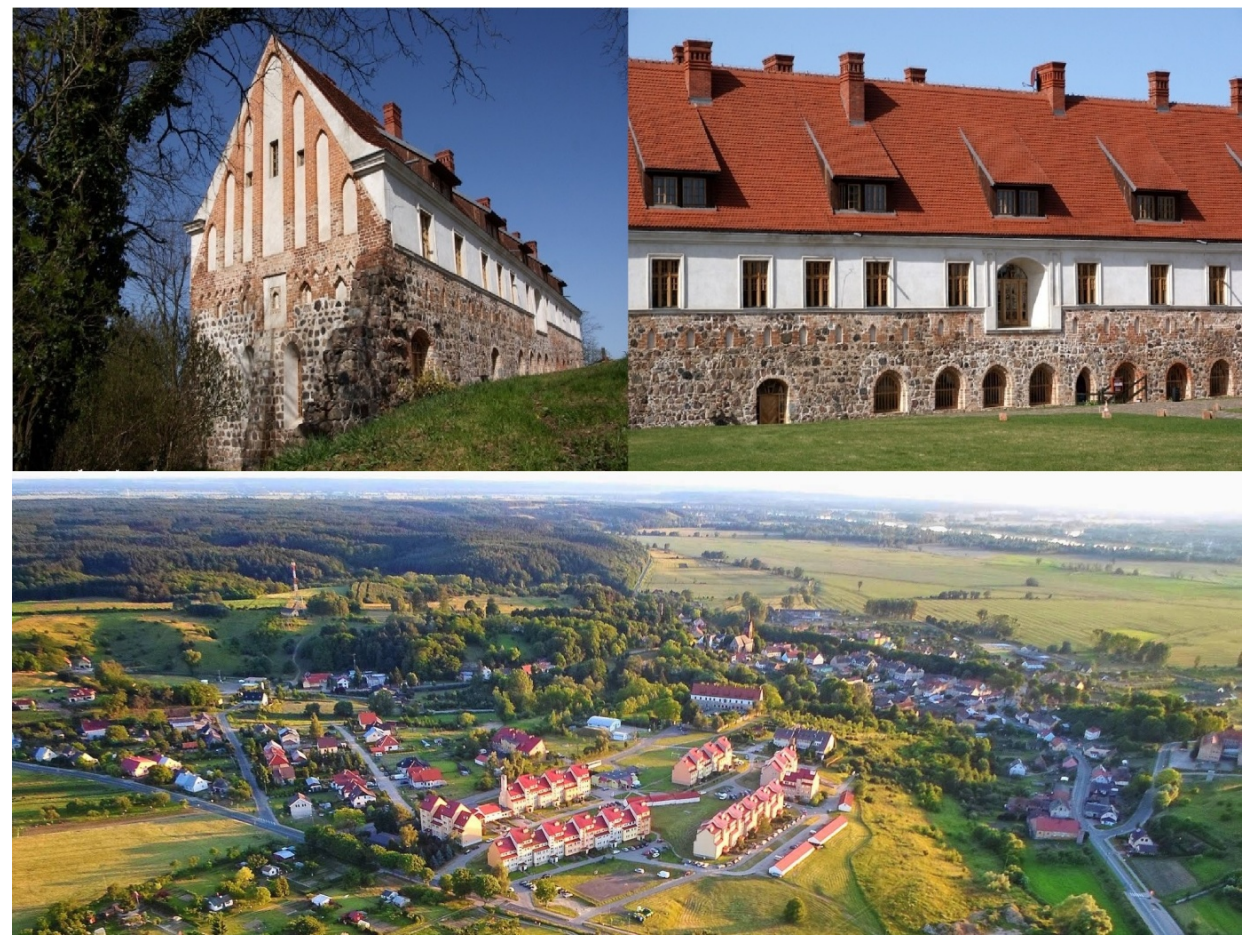

Ryc. 4. Klasztor Cysterek: budynek klasztorny, wejście na dziedziniec oraz blokowisko naprzeciwko kompleksu klasztornego (stan: 2017 r.)

Zródło: cedynia.pl

Podczas lokacji osady, na przecięciu wcześniej opisanych traktów (ryc. 2), w sposób naturalny wytyczony został cedyński pochylony rynek. Uporządkowano wówczas istniejący układ przestrzenny, bazujący na wczesnośredniowiecznej sieci drożnej. Na wzniesieniu pomiędzy traktami chojeńskim i moryńskim wzniesiono zabudowania klasztorne; wtedy też powstał kościół parafialny (ob. pw. Narodzenia Najświętszej Marii Panny - ryc. 5), zbudowany na południe

${ }^{5}$ W 1295 r. Cedynia została wspomniana w bulli papieża Bonifacego VIII (Bullarium Poloniae 1982, s. 169). 
od drogi do Morynia. Miejscowość rozwijała się u stóp wzgórza klasztornego, którego zabudowa górowała nad całością osady (Rymar 2013). Drugą dominantą przestrzenną był wspomniany wcześniej kościół z XIII w. zbudowany w formie jednonawowej z prostym prezbiterium i wieżą, z ciosów granitowych z polnego kamienia (ryc. 6).

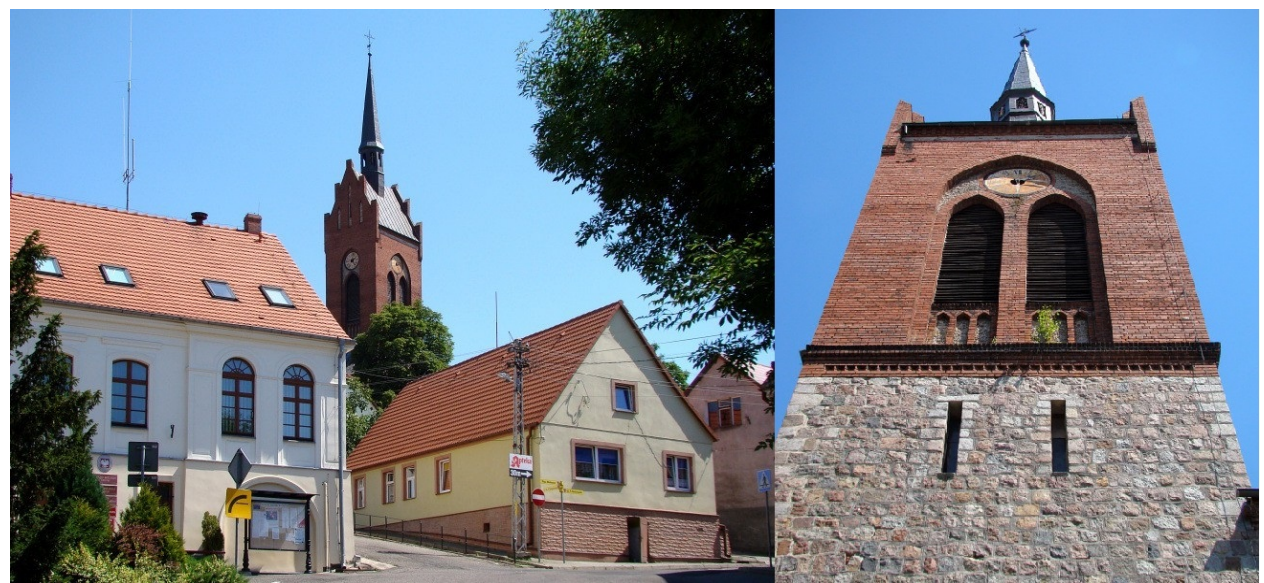

Ryc. 5. Kościół pw. Narodzenia Najświętszej Marii Panny (stan: 2017 r.) Źródło: cedynia.pl

Cedynia nie została nigdy wyposażona w opaskę murów miejskich; warunki stworzone przez naturalnie ukształtowane elementy rzeźby terenu zapewniały jej wystarczającą ochronę. W okresie średniowiecznym miasto tylko w nieznacznym stopniu korzystało z otaczającej je przestrzeni. Tereny wykorzystywane rolniczo znajdowały się na północ i wschód od zabudowy miasta. Od zachodu osadę otaczały rozległe bagna i rozlewiska doliny Odry. Wzgórza wokół porastał niemal w całości las. Podstawą egzystencji mieszkańców było w znacznym stopniu rybołówstwo (Rymar 2013).

Liczne zmiany przyniósł okres nowożytny. Po wprowadzeniu w Nowej Marchii wyznania reformowanego, dobra klasztoru Cysterek zostały przejęte (1555 r.) przez margrabiego Jana Kostrzyńskiego. Początkowo zabudowania wykorzystywano jako dom dla panien pochodzenia szlacheckiego, prowadzony przez byłe zakonnice. W $1611 \mathrm{r}$. dawny klasztor stał się siedzibą domeny; doprowadziło to do przebudowy jego zabudowań do nowych potrzeb. W latach 40. XVII w. zespół przekształcono w okazałą rezydencję z licznymi budynkami gospodarczymi. Klasztor przebudowano na zamek myśliwski dla elektorów. Przy rozległym dziedzińcu dobudowano stajnię, obory, masztalernię oraz budynek rządcy. Domenę rozbudowano również o nowe tereny upraw. W XVII w. należało do 
niej dwanaście ogrodów, położonych nad stawem młyńskim, nad Młynnicą oraz w pobliżu Parchnicy i bezpośrednio pod dawnym klasztorem. Na południowym stoku wzgórza, przy zabudowaniach, założono ogród kwaterowy typu włoskiego (Kościelna 2014). Miasto w tym czasie utrzymało swój rybacko-rolniczy charakter i wyglądało jak na panoramie Meriana (ryc. 6). W sylwecie miasta dominował nadał budynek kościoła oraz wiatrak koźlak, ustawiony w miejscu, gdzie dziś znajduje się cmentarz komunalny. Zabudowa miała, z wyjątkiem zabudowań domeny, przede wszystkim charakter wiejski. Znajdował się tam również młyn wodny, położony w południowej części miasta (Gut 2013, 2014).

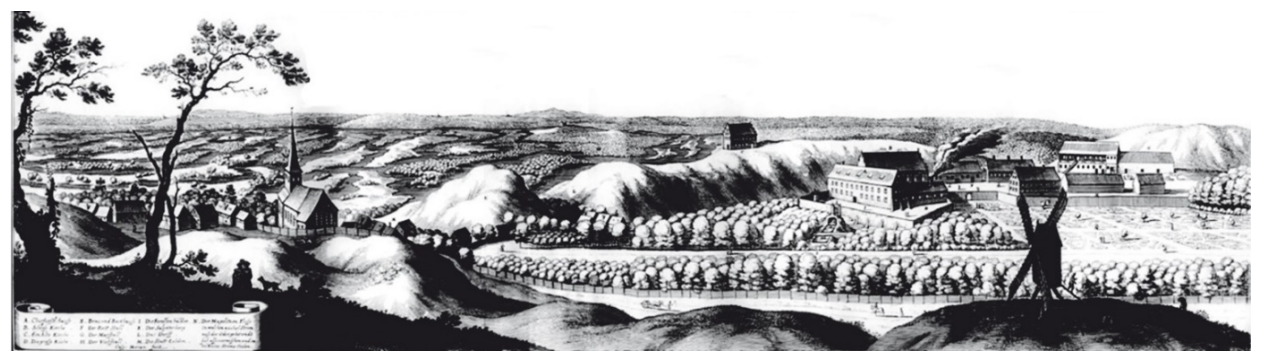

Ryc. 6. Cedynia na panoramie Meriana z 1652 r. Źródło: Antykwariat Sobieski

W drugiej połowie XVIII w. zaszło wiele wydarzeń mających wpływ na wygląd i strukturę miejskiej zabudowy. Zburzono stary kościół pocysterski oraz budynek kuchni, położony po południowo-zachodniej stronie dziedzińca dominium (Gut 2013, 2014). Gruntownie odremontowano kościół parafialny, który uległ jednak pożarowi w 1699 r.; oprócz świątyni spaliły się zabudowania parafii, domy mieszczańskie w jego bezpośrednim otoczeniu oraz budynek ratusza. Zabudowa miejska w XVIII w. wzniesiona była przede wszystkim w technice ryglowej, większość dachów ciągle pozostawała kryta strzechą (Kościelna 2014). Na przełomie XVIII-XIX w. wydrążono w skarpie wzgórza piwnice, składające się z kilku pomieszczeń. Służyły one do przechowywania wina oraz innych produktów spożywanych (obecnie są nieużytkowane).

W XIX w. stare, mniej trwałe pokrycia dachów zastąpiono dachówką, w czasach PRL zaś znaczną ich część odnowiono z użyciem materiałów zawierających azbest (Program... 2008). W zabudowie dominowały budynki parterowe, tylko część zabudowy wokół rynku miała większą liczbę kondygnacji (ryc. 2). W 1811 r. domena cedyńska została zlikwidowana. Dawny zespół klasztorny przejął Królewski Urząd Pocztowy. W XIX w. rozpoczęla się także stopniowa wymiana dawnej ryglowej zabudowy na znacznie trwalszą, murowaną (ryc. 7). 


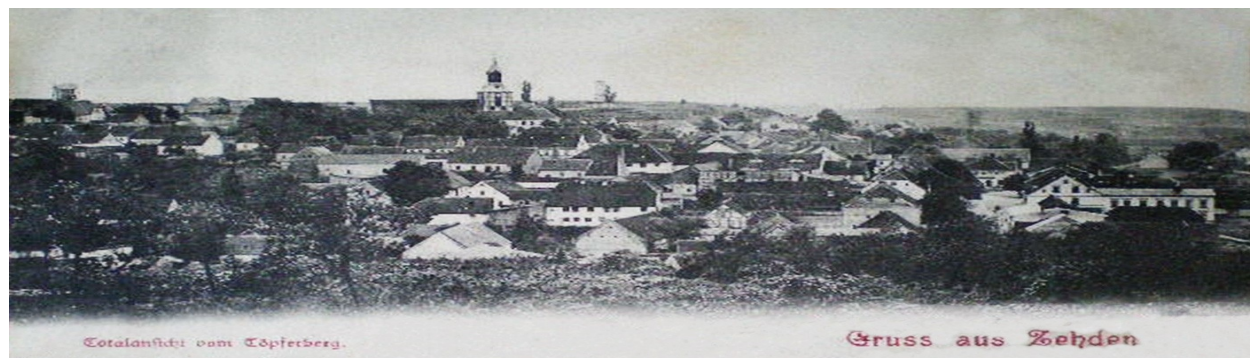

Ryc. 7. Panorama Cedyni z lat 1890-1898

Źródło: cedynia.fotopolska.eu

Największe prace budowlane w XIX w., wpływające na zabudowę Cedyni i jej otoczenia, miały miejsce w latach 1854-1858 (Schmook 2013). Zbudowano wtedy na wysokości miasta wał przeciwpowodziowy, a w latach 1863-1864 Kanał Ulgi, zbierający nadmiar wód z otaczających miasto terenów zalewowych. Osuszenie rozległych terenów Polderu Cedyńskiego otworzyło mieszkańcom nowe, bardzo wartościowe pod względem warunków glebowych, tereny rolnicze. Na całej długości Kanału Ulgi, przechodzącego przez miasto, posadzono aleje kasztanowców (ryc. 8). Uregulowanie stosunków wodnych w tym rejonie umożliwiło miastu pozyskanie nowych terenów pod zabudowę. Przy nowo wybudowanej drodze w kierunku Osinowa Dolnego wytyczono działki siedliskowe, zabudowane później domami jednorodzinnymi i zagrodami. W tym czasie w Cedyni funkcjonowały dwa młyny (wodny i parowy), cztery wiatraki na południowych krańcach terenów miasta oraz tartak, gorzelnia i dwie cegielnie (Studium... 2017).

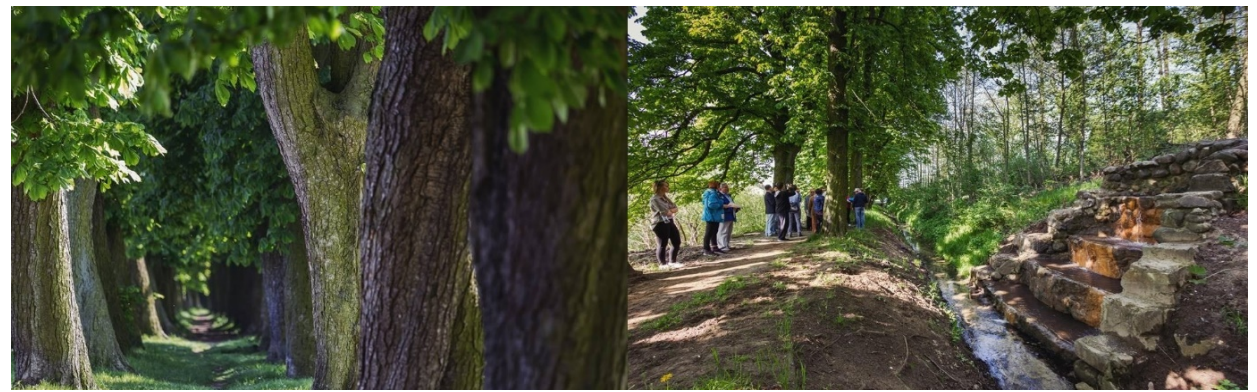

Ryc. 8. Aleja kasztanowa i odcinek Kanału Ulgi z kamienną kaskadą (stan: 2017 r.) Źródło: cedynia.pl

Pod koniec XIX w. miasto otrzymało neogotycką, 14-metrową wieżę widokową (ryc. 9). Została ona zbudowana za rządów burmistrza Cedyni Ernesta Melchera, ku czci poległych podczas wojen Prus z Danią (1864 r.), Austrią 
(1866 r.) i Francją (1870-1871). W dolnej części wieży znajdowała się tablica z nazwiskami poległych (zniszczona w $1945 \mathrm{r}$.).

Początek XX w. przyniósł dalszy rozwój zwartej zabudowy miejskiej (ryc. 2). W latach 30. wznoszono liczne, nowe domy, szczególnie we wschodniej części miasta, przy drodze prowadzącej w kierunku Radostowa (Schmook 2013). Zbudowano dworzec kolei wąskotorowej wraz z lokomotywownią, stanowiący końcową stację lokalnej linii. Do Cedyni przedłużono tory kolei wąskotorowej z Bad-Freienwalde (Oder). Jednotorowa linia została otwarta 30 października 1930 r. (Schmook 2013).

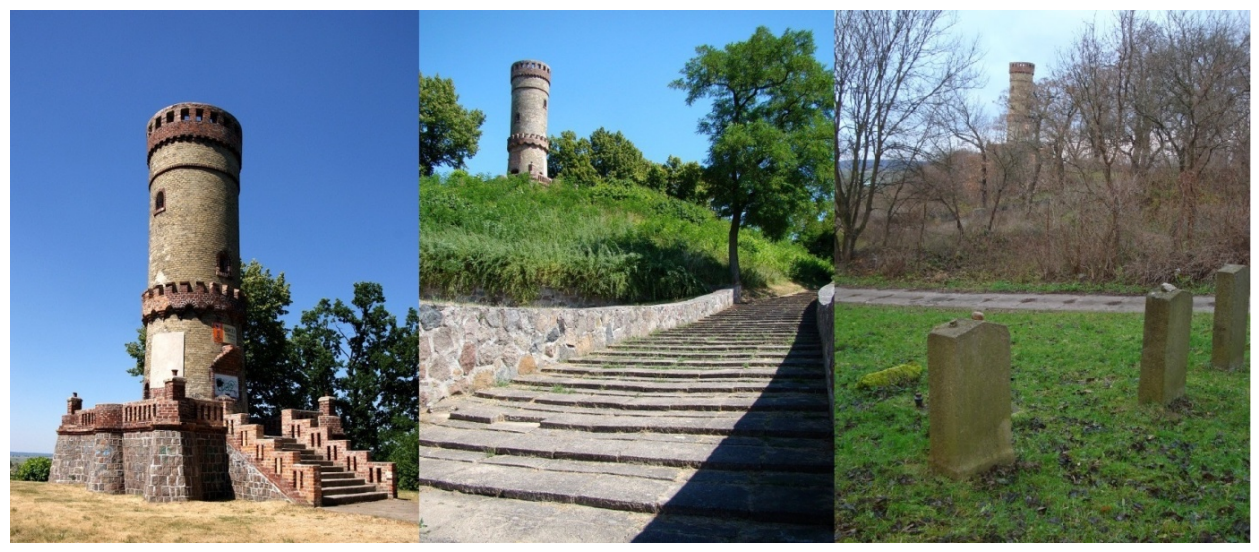

Ryc. 9. Neogotycka wieża widokowa oraz kirkut (stan: 2012 r.). Wieża widokowa do 1956 r. była użytkowana przez Wojska Ochrony Pogranicza. Obecnie jest obiektem turystycznym, z którego otwiera się panorama na polską i niemiecką stronę granicy państwowej. Kirkut znajduje się w pobliżu wieży widokowej. Cedyńscy społecznicy uporządkowali pozostałości żydowskiego cmentarza; na obszarze ok. 0,2 ha ustawiono ponownie siedem macew, z których najstarsza pochodzi z 1770 r. W 2002 r. kirkut został

wpisany do rejestru zabytków województwa zachodniopomorskiego (stan: 2017 r.) Źródło: cedynia.pl

Druga połowa minionego stulecia przyniosła więcej strat i na dłuższy czas zahamowała rozwój miasta. W 1945 r. Cedynia wraz z innymi terenami Pomorza Zachodniego została zasiedlona przez ludność polską. Nowi osadnicy przybyli ${ }^{6}$ i przejęli miasto zniszczone w $48 \%$ na skutek działań wojennych. Do końca

\footnotetext{
${ }^{6}$ Nowymi osadnikami przeważnie byli ludzie z Wołynia, okolic Tarnopola i żołnierze wracający spod Berlina oraz więźniowie obozów pracy z terenu III Rzeszy. ,[...] W maju 1945 r. na Pomorzu Zachodnim w dalszym ciągu przebywało 843765 obywateli niemieckich [...]. Głównym problemem związanym z integracją tzw. Ziem Odzyskanych była szeroko rozumiana akcja osadnicza [...] w dwunastu nadgranicznych powiatach: Kamień Pomorski-Wolin, Gryfino, Chojna, Sulęcin, Rzepin, Krosno Odrzańskie, Żary,
} 
lat 60. w zasadzie nie wznoszono w mieście nowej zabudowy. Później, od lat 70., budowano przede wszystkim obiekty użyteczności publicznej, jak pawilony sklepowe czy budynek restauracji. Na części terenów zalewowych powstał rozległy kompleks Państwowego Gospodarstwa Rolnego Cedynia, które zajęło tereny dawnego dworca kolei wąskotorowej
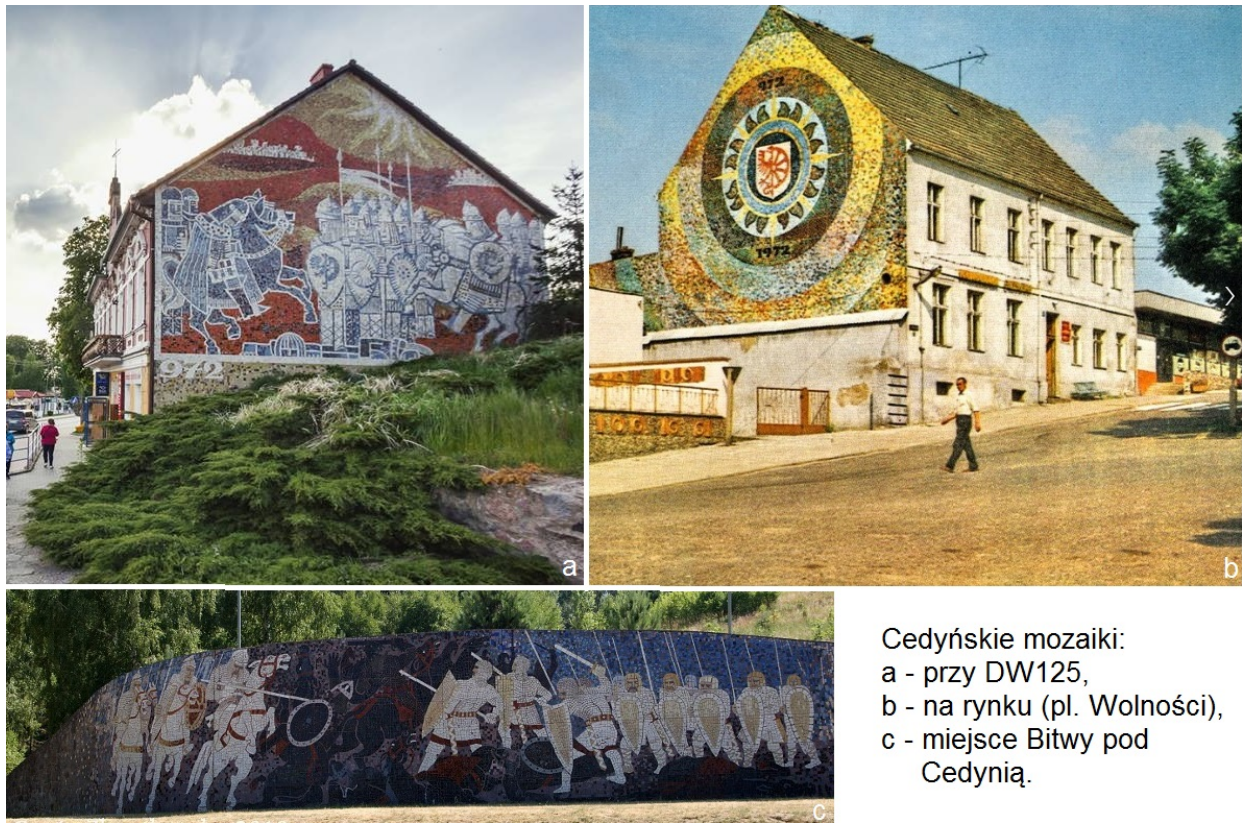

Cedyńskie mozaiki:

a - przy DW125,

b - na rynku (pl. Wolności),

c - miejsce Bitwy pod Cedynią.

Ryc. 10. Cedyńskie mozaiki odsłonięte w 1972 r. (stan: a - 2017 r., b - 1972 r., c - 2010 r.) Źródło: cedynia.pl

Żagań, Gubin, Zgorzelec, Lubań i Lwówek Śląski. W miejsce po Niemcach tereny te mieli więc zasiedlić zdemobilizowani żołnierze ze swoimi rodzinami. [...] Głównym powodem akcji była chęć zabezpieczenia granic, co wynikało z niepewności w kwestii utrzymania ówczesnego województwa szczecińskiego w granicach Polski Ludowej. Zdemobilizowani żołnierze [...] stali się tym sposobem swoistą zaporą [...]. Po [...] usprawnieniu administracji publicznej na Ziemiach Odzyskanych [...] realizację tego zamierzenia regulowało wspólne zarządzenie wydane przez MON, Ministerstwo Administracji Publicznej oraz Ministerstwo Rolnictwa i Reform Rolnych z 24 września 1945 r. [...] Pierwsi polscy osadnicy pojawili się tu bezpośrednio po przejściu frontu, już w lutym i marcu 1945 r. Był to żywiołowy okres osadnictwa, nieregulowany normami prawnymi i wyprzedzający działalność władz administracyjnych. Osadnikami byli głównie ludzie z przygranicznych powiatów [...]. 3 grudnia 1950 r. [...] według wyników [Narodowego Spisu Powszechnego] na poniemieckich ziemiach [...] w porównaniu do czasów przed wojną, były i tak niedoludnione. Powody były różne: od braku chęci powrotu z Zachodu po trudności z tym związane, czynione przez ZSRR" (Morawska 2015). 
Z okazji tysięcznej rocznicy bitwy pod Cedynią wybudowano w $1972 \mathrm{r}$. pomnik na Górze Czcibora przy drodze do Osinowa Dolnego (ryc. 3) oraz wykonano trzy ceramiczne mozaiki, w tym dwie - upamiętniające scenę bitwy pod Cedynią (ryc. 10). Znaczącym faktem dla mieszkańców miasta było wybudowanie w latach 80 . nowego, rozległego kompleksu szkolnego w bezpośrednim otoczeniu dawnego grodziska. Obecnie znajduje się w nim szkoła podstawowa i gimnazjum.

\section{Tkanka urbanistyczna i koncepcja morfoznaku}

Tkanka urbanistyczna (tissu urbain) Cedyni, tj. kompozycja zabudowy składająca się z mniejszych elementów, jak budynki, ulice, place, dziedzińce, stanowiąca o jej tożsamości, była tworzona przez grupy kulturowe z czasów: a) kultury łużyckiej, b) Mieszka I, c) Książąt Pomorskich, d) Nowej Marchii, e) Prus i f) PRL. Zgodnie z H. Lefebvre (2009) substancja ustalonych a priori struktur miejskich potrafi narzucić mieszkańcom styl życia (czymkolwiek jest). Pytaniem jest, czy obecni osadnicy chcą przyjąć pruski bądź peerelowski styl życia, narzucony przez tkankę urbanistyczną Cedyni? Czy raczej wolą przejąć piastowskie genius loci, natomiast a priori daną im substancję miejską z elementami powstałymi w okresie Prus i PRL (wiedząc o historii ich powstania) przystosować do własnego stylu życia, oddając jednocześnie hołd pamięci twórcom historycznym.

Koncepcja morfoznaku rozpatruje elementy fizykalne tkanki miejskiej za pomocą kodu obrazowego morfoznaku (ryc. 11), natomiast stosunek do nich poznaje za pośrednictwem kodu semantycznego (ryc. 12) tychże elementów. Termin „morfoznak” powstał przez połączenie „morfo” i „,znak”. „Morfo” pochodzi z greckiego morphe (kształt) i odnosi się do zbioru czterech niepodzielnych elementów fizycznych zwanych morfoznakami, tj.: ulica, plac, budowla, zieleń (ryc. 11); służą one ludziom do kształtowania najprostszych zagród (nawet tych, z początku dziejów ludzkości) i największych metropolii wszech czasów. Drugi człon terminu - znak - jest pojęciem zapożyczonym z językoznawstwa; jest jednostką dającą konwencjonalną informację o abstrakcyjnych, niepodzielnych elementach fizycznych planu miasta (Pirveli 2011). Znaki wyróżnione w ramach każdego morfoznaku są dwuskładnikowe. Znak składa się z oznacznika i ze znaczenia. Oznacznik wyraża się kodem obrazowym (ryc. 11), a znaczenie - kodem semantycznym (ryc. 12).

Kod obrazowy jest to coś, co widać, co jest łatwo dostrzegalne zarówno w planie miasta, jak i w przestrzeni oraz na fotografii. Obraz, tj. wygląd, zależy 
od parametrów geometrycznych znaku (kształtu, gatunku i gabarytów), cech architektonicznych, od materiału budowlanego i wykończeniowego, ale także od tego, do czego ma służyć bądź służy dany znak. Inaczej wygląda morfoznak aleja kasztanowa (ryc. 8) i ulica Krótka (ryc. 13), czy DW 124 i DW 125, czy morfoznak - budowla klasztor Cysterek i blokowiska (ryc. 4), czy dom mieszkalny, świątynia (ryc. 5), wieża (ryc. 9), czy plac-skrzyżowanie, plac-pochylony rynek, plac-podwórko, plac cmentarz-kirkut lub morfoznak - zieleń-uliczna, zieleń-ugory miejskie, zieleń-doniczkowa ${ }^{7}$ ).

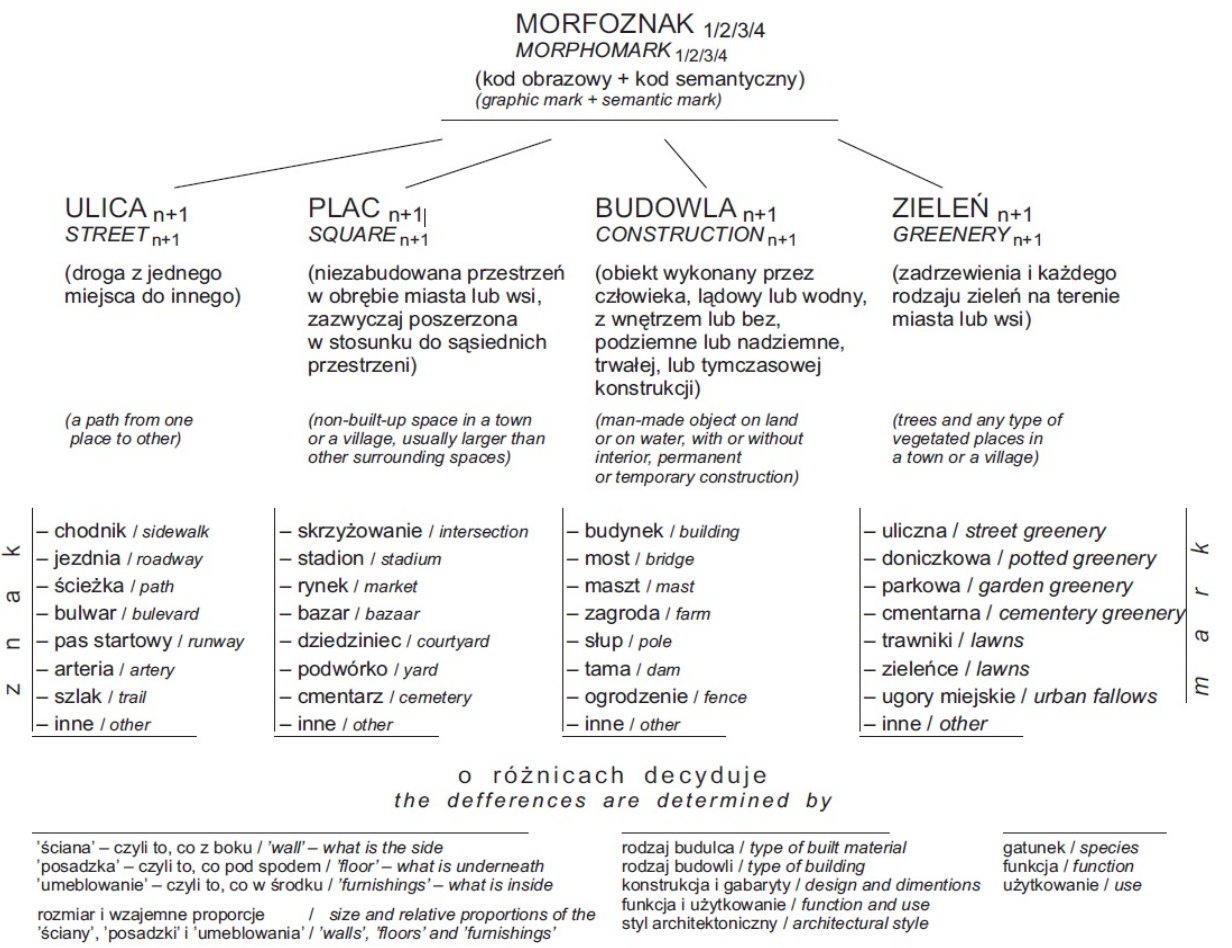

Ryc. 11. Morfoznak i znak

Źródło: M. Pirveli (2011)

${ }^{7}$ Cedynianie, podobnie jak mieszkańcy wielu innych miast, upiększają swoją przydomową przestrzeń i biorą udział $\mathrm{w}$ organizowanych cyklicznie w konkursie pod tytułem „Kwiatami Cedynię upiększamy” (Konkurs....). 


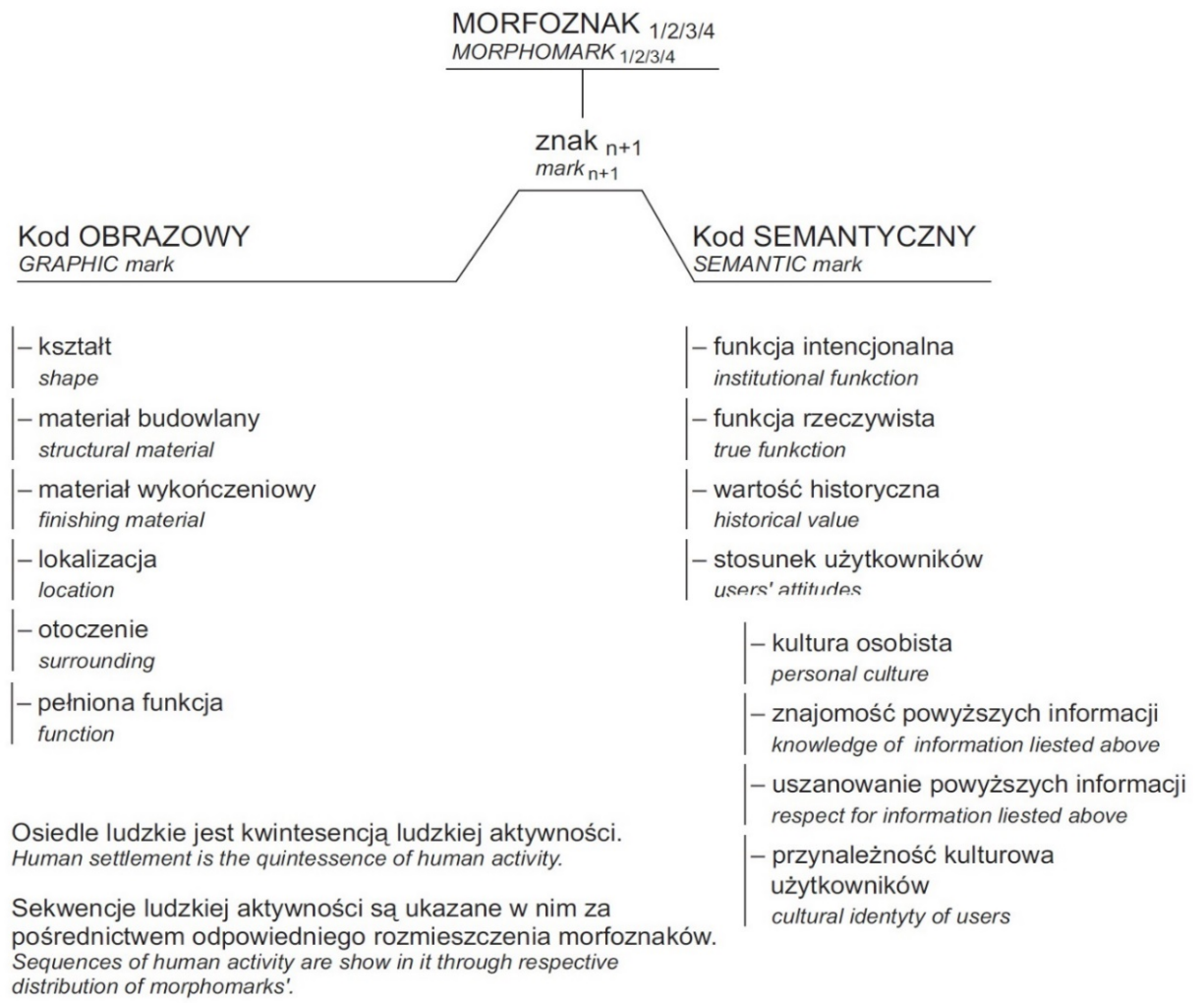

Ryc. 12. Kod obrazowy i semantyczny Źródło: M. Pirveli (2011)

Bardziej skomplikowanie przedstawia się sprawa kodu semantycznego. Kod semantyczny jest niewidoczny. Podstawą wyrobienia jego treści jest znajomość faktów oraz stosunek mieszkańców miejscowości do najbliższego otoczenia. Kod semantyczny znaków powstałych w obrębie czterech morfoznaków wynika:

1. $Z$ obecnie pełnionej przez morfoznak funkcji - nadanej przez, przykładowo, władze lokalne lub społeczność lokalną, jak: letnia kawiarenka sąsiedzka, która powstała w Cedyni maju 2017 r. przy placu Wolności i ulicy Krótkiej jako czyn społeczny (Piątek 2017). Kilkadziesiąt cedynian postanowiło dokonać zmiany w najbliższym otoczeniu. Przygotowali oni przy rynku, w miejscu niezorganizowanego parkingu, w otoczeniu zieleni i kwiatów miejsce do sąsiedzkich spotkań (ryc. 13).

2. Z pierwotnego przeznaczenia danej formy, która ulega zmianie - wartości historycznej, jak: 14-metrowa wieża, która została zbudowana w 1895 r. ku czci poległych podczas wojen Prus z Danią, Austrią i Francją; w lutym 1945 r. wieża 
służyła Armii Czerwonej jako punkt obserwacyjny (ryc. 9), a obecnie jest punktem widokowym, z którego otwiera się panorama na Cedynię; albo wydrążone w skarpie wzgórza piwnice będące najpierw spiżarnią, potem magazynem PGR, a obecnie niszczeją, czekając na odrodzenie.

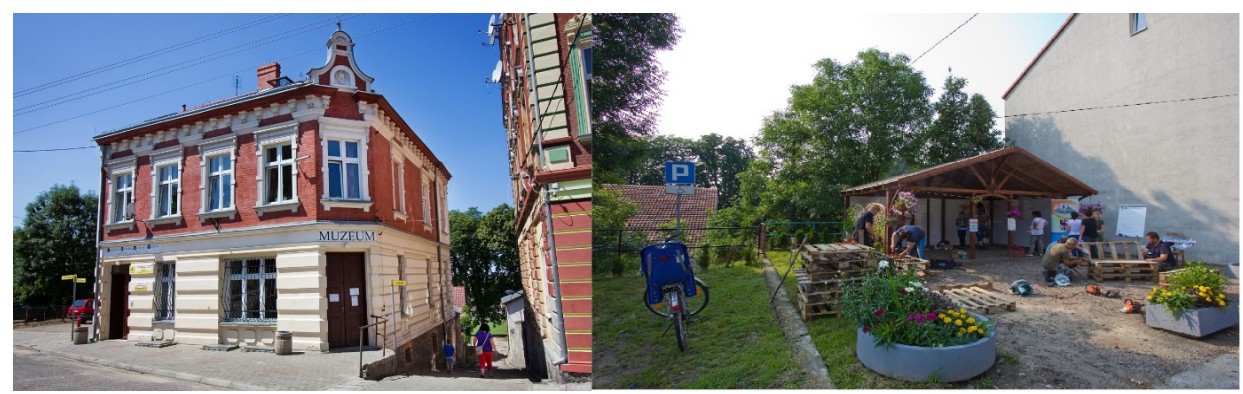

Ryc. 13. Zabytkowa kamienica pod adresem pl. Wolności 4. Siedziba Muzeum Regionalnego oraz Cedyńskiego Ośrodka Kultury i Sportu. Po lewej stronie budynku widać parking, a z prawej - ul. Krótką, prowadzącą do alei kasztanowej. Na miejscu parkingu mieszkańcy Cedyni stworzyli kawiarenkę sąsiedzką (stan: 2017 r.) Źródło: cedynia.pl

3. Z wartości architektonicznej formy - jak kamienice przy rynku (ryc. 13).

4. Ze stosunku obecnych użytkowników do danego elementu fizykalnego, co wynika: $\mathrm{z}$ zaznajomienia i uszanowania informacji w wyżej wymienionych punktach, z cech kulturowych i z kultury osobistej użytkownika, ze światopoglądu i głębi wiedzy, jak chociażby w przypadku uporządkowania kirkut przez cedyńskich społeczników (ryc. 9).

Stosując koncepcje morfoznaku do badań, wychodzi się z założenia, że każda epoka oraz każda kultura w danej epoce kreuje i ustala własne normy, własny szyk i porządek łączenia ze sobą czterech morfoznaków (funkcje syntaksy, tj. sposobu łączenia morfoznaków ze sobą, pełni kultura rozumiana według komunikacyjnej teorii kultury E.T. Halla (1987). Połączone ze sobą morfoznaki dają miejską tkankę najprostszych ludzkich osad i wielkich metropolii. Cedynia jest jednym $\mathrm{z}$ wielu przykładów miast, którego przestrzeń była tworzona w czasie przez grupy społeczne z odmiennych kręgów kulturowych. Żywa kultura (Obserwatorium...) i subkultura (pojęcie według M.M. Gordon) ${ }^{8}$ obecnych cedynian:

${ }^{8}$ Subkultura określa grupę społeczną i jej kulturę wyodrębnioną według jakiegoś kryterium np. zawodowego, etnicznego, religijnego, demograficznego itp. Subkultura jest segmentem kultury i nie podlega wartościowaniu na wyższą czy niższą (Gordon 1947). 
- współtworzą kod semantyczny cedyńskich morfoznaków,

- modyfikują znaki i ich funkcje (które nie mają jednoznacznych związków między sobą), przystosowują je do panujących we własnym kręgu wzorców socjokulturowych zgodnych z potrzebami cedyńskiej wspólnoty bądź zbiorowości terytorialnej (na tej płaszczyźnie ujawnia się rola kultury odpowiedzialnej za syntaks, tj. za modyfikacje i łączenie znaków),

- ustalają własne techniki egzekwowania lokalnie ustalonych reguł prawa zwyczajowego i kodyfikowanego.

\section{Substancja Cedyni: formy, ludzie, procesy}

Kompozycja zabudowy złożona $\mathrm{z}$ opisanych wyżej mniejszych elementów (budynków, ulic, placów, dziedzińców itd.) razem tworzą substancję Cedyni i zasady zachowania w przestrzeni publicznej (Jasiński 2010, s. 173-174). Ożywia je stosunek cedyńskiej subkultury do nich. Cedyńska subkultura jest określona grupą społeczną mieszkańców i jej kulturą wyodrębnioną według kryterium zawodowego, etnicznego, religijnego, demograficznego (Gordon 1947). Wyrosła ona z kultury przywiezionej przez powojennych osadników, którzy swoje genius loci (dziedzictwo) zostawili na wschodzie i którym narzucono funkcjonowanie - po pierwsze - w kulturowo innej przestrzeni i - po drugie - w warunkach gospodarki centralnie planowanej (sterowanej dekretami) (Zblewski 2001, s. 37). Obecni obywatele Cedyni to następne pokolenie powojennych osadników oraz ci, którzy z własnej woli przybyli do miasta w ciągu ostatnich lat. Żyją i działają w warunkach wolnego rynku i Gospodarki Opartej na Wiedzy (GOW) oraz wiedzą, że mają pełne „prawo do miasta” (Lefebre 2009, Harvey 2012, Marcuse 2013). Oznacza to m.in., że będąc interesariuszem ${ }^{9}$ w partycypacyjnie programowanym procesie rewitalizacji, mieszkańcy obok przedstawicieli lokalnych instytucji sektora publicznego, prywatnego i społecznego mogą deklarować własny stosunek do znajdujących się w najbliższym otoczeniu form fizycznych, definiować problem z własnej perspektywy i proponować kierunek zmian. Czy i jak przekłada się wiedza o swoich prawach do miasta na współkształtowanie Cedyni jest podstawą mówienia o tożsamości transgranicznego miasteczka.

Od początku 2017 r. mieszkańcy gminy brali udział w partycypacyjnym opracowaniu programu rewitalizacji $\mathrm{w}$ gminie Cedynia ${ }^{10}$. Partycypacyjny cha-

${ }^{9}$ Interesariusze - są to mieszkańcy, organizacje pozarządowe, osoby prywatne, podmioty publiczne lub inne organizacje, zlokalizowane na terenie objętym programem rewitalizacji.

${ }^{10} \mathrm{http}: / /$ Cedynia.pl 
rakter prac polegał m.in. na poznaniu potrzeb i oczekiwań interesariuszy, dążeniu do spójności planowanych działań z ich potrzebami i oczekiwaniami, prowadzeniu skierowanych do interesariuszy działań edukacyjnych i informacyjnych o procesie rewitalizacji i o jego przebiegu, zapewnieniu udziału wszystkich zainteresowanych $\mathrm{w}$ przygotowaniu dokumentów dotyczących rewitalizacji (Górski 2016, s. 89-95, Śleszyński i in. 2016, s. 14-25). Ścisły kontakt z interesariuszami zapewniały: warsztaty, debaty i konsultacje społeczne, robocze spotkania, których celem było ustalenie zawartości ankiety do badań sondażowych, stopnia szczegółowości objaśnień do wzoru wniosku, który osoby zainteresowane mogły wypełnić i złożyć jako propozycje własnego wniosku, a także akcje typu „zróbmy coś razem”. Podczas wszystkich etapów procesu partycypacji oraz $\mathrm{w}$ trakcie wszelkich procesów oddziaływań zachodzących między uczestnikami odbywała się ciągła wymiana informacji oraz następowała ewolucja relacji mieszkańców do Cedyni - jako do swojego miejsca, do własnej osoby widzianej jako ważna postać w lokalnej strukturze społecznej oraz do władz samorządowych, widzianych w roli partnera do rozmów. U uczestników procesu partycypacyjnego programowania zmian była możliwość zaobserwowania „co się dzieje między ludźmi i dlaczego”, co jest powiązane z pytaniem, jak społeczność cedyńska powstaje (Sieradzki 2011, s. 144).

Przed zaprezentowaniem jedynie małej części wyników przeprowadzonych badań ważne jest podkreślenie, że obywatele Cedyni, podobnie jak obywatele innych miast środkowoeuropejskich ${ }^{11}$, uczą się widzieć swój problem w kontekście potrzeb zbiorowych oraz jak mieć „prawo do miasta”, a ich miasta (zarządzane przez młodych i starszych samorządowców wybieranych z ich szeregów) „uczą się" mieć swoje prawa i widzieć potrzeby zbiorowe z perspektywy potrzeb indywidualnych mieszkańców. Przy czym, świadomość różnicy między dwiema kategoriami praw oraz stopień kompatybilności tych dwóch kategorii praw (prawo do miasta oraz prawa miasta) decyduje o powodzeniu podejmowanych w mieście działań i w rezultacie o sukcesie miasta jako instytucji (patrz: Harvey 2012, Marcuse 2013).

${ }^{11}$ Europa Środkowo-Wschodnia, nazwa - według Oskara Haleckiego - stosowana dla określenia europejskich państw mających wspólne korzenie kulturowe i historyczne, a także wspólną przeszłość jako buforowe socjalistyczne republiki podlegające ZSRR (demoludy) lub będące jego częścią składową jako republiki radzieckie. Jest to zbitka dwóch określeń tej części Europy - geograficznego (środkowa) i politycznego (wschodnia). Stało się ono bardziej popularne od lat 80., gdy trzej intelektualiści (Milan Kundera, Czesław Miłosz i István Bibó) użyli go jako przeciwwagi dla terminu Europa Wschodnia. Łącznie do tego regionu zalicza się ok. 18 państw (Szúcs 1995, Kłoczkowski 1998, Lewandowski, Goleman 1999). 
Na płaszczyźnie współdziałania interesariuszy na rzecz wspólnej przestrzeni zwanej Cedynią, najtrudniejsze okazuje się nie postrzeganie wartości artefaktów z przeszłości, lecz rozwiązanie problemu integracji społecznej, komunikacji i zaufania nie tylko między stronami dialogu, lecz wewnątrz poszczególnych grup interesariuszy. Słaba jest również umiejętność widzenia w publicznej przestrzeni miasta wspólnej wartości, od którego zależy nie tylko sukces poszczególnych osób i grup społecznych, lecz jakość życia w mieście ${ }^{12}$. Używając terminologii D. Harveya (1982) opisującej proces zachodzący między obok siebie występującymi i nakładającymi się przestrzeniami (w mieście) z perspektywy kumulacji kapitału, w Cedyni następuje próba „naprawiania przestrzeni” (space fix) poprzez „tarcie przestrzeni” (friction of space) wytworzone przez grupy ludzi po stronie sektorów prywatnego i publicznego oraz społecznego (w sensie samorządu lokalnego i bardzo słabego sektora instytucji pozarządowych). Wpływa to na niską integrację sił pochodzących z tych trzech życiodajnych sektorów. Konsensus między reprezentantami poszczególnych sektorów zależy prawdopodobnie od ich świadomości wspólnej przestrzeni jako wspólnej wartości oraz umiejętności komunikacji i podmiotowego traktowania partnera dialogu (osoby bądź instytucji), obdarzania abstrakcyjnym zaufaniem działań sektora samorządowego jako instytucji, pod której dyrekcją jest zarządzanie Cedynią. Przy czym, Cedynia jako całość jest to zbiór odmiennych elementów i kompleksów przestrzennych oraz form organizacyjnych, które są użytkowane przez różne instytucje, grupy społeczne i osoby zamieszkujące lub tylko odwiedzające miasto.

Z badań kwestionariuszowych przeprowadzonych w marcu i kwietniu $2017 \mathrm{r}$. wynika (LPR 2017), że respondenci niepokoją się złym stanem estetycznym obiektów zabytkowych (15\%), stanem technicznym budynków (14\%) i zabytków (5\%), dysfunkcją społeczną (14\%), ubóstwem (3\%), przestępczością (1\%), brakiem miejsc pracy (7\%), małą dostępnością do komunalnych zasobów mieszkaniowych (7\%). Przeszkadzają im wąskie chodniki (10\%), brak całodobowego komisariatu policji, zagradzane dziedzińce kamienic, zanieczyszczone zwierzęcymi odchodami ulice (4\%), słaba aktywność mieszkańców (10\%), słaby rozwój handlu i usług (2\%), słabo rozwinięta baza turystyczno-rekreacyjna (7\%).

Zdecydowanie są to cechy negatywne i powinny być minimalizowane lub w pełni rozwiązane. Pytaniem jest, gdzie są i jakie są źródła ich pochodzenia

12 Jakość życia - konsensus między stylem życia mieszkańców (kto, co, gdzie, jak preferuje działać) a warunkami życia (tzn. na ile infrastruktura przestrzenna pozwala realizować to, co wynika ze stylu życia), jakie swoim mieszkańcom zapewnia Cedynia jako instytucja miejska (gmina). 
oraz na ile źródła te mogą wpłynąć na tożsamościowy obraz Cedyni. Po części źródła „zatopione” są (prawdopodobnie) na różnych płaszczyznach:

a) w słabości finansowej gminy lub w braku umiejętności respondentów ustalić kolejność problemów do rozwiązania albo wynika z chęci wskazywania faktu, co jeszcze nie zostało rozwiązane (stan estetyczny i techniczny, wąskie chodniki),

b) w niepostrzeganiu przestrzeni publicznej jako własnej (co poza domem to nie moje: ulice zanieczyszczone odchodami, zagradzane dziedzińce),

c) w słabym rozwoju sektora społecznego i takiej samej świadomości obywatelskiej (dysfunkcja społeczna jako problem najczęściej jest rozwiązywany przez ekonomię społeczną, która uczy również przedsiębiorczości),

d) w niezgodności norm i zasad funkcjonowania lokalnej społeczności bądź odmiennym odczuwaniu bezpieczeństwa oraz przyczyn zapewniających poczucie bezpieczeństwa (całodobowy komisariat).

Dojście do źródła pochodzenia wymaga poznania stylu życia gospodarzy miasta (tzn. kto, co, gdzie, jak preferuje działać), czego nie da się dokonać bez dobrej woli mieszkańców i wszystkich interesariuszy, miejsc o odpowiednim klimacie, całego spektrum wydarzeń edukacyjno-informacyjno-rekreacyjnych, odwagi i swobody wypowiedzi oraz braku poczucia zagrożenia z powodu otwartości na forum sąsiedzkich debat. W Cedyni widoczne są już kroki podejmowane w tym kierunku, jak choćby akcja „zróbmy coś razem” czy portal cedyniabezcenzury.pl. Podczas akcji społecznych cedynianie porządkowali przestrzeń w mieście. Na regularnie aktualizowanej stronie internauci pod pseudonimem (NIK) wypowiadają się na temat bieżących wydarzeń. Każda zainteresowana osoba może wchodzić, poznać i komentować aktualną wiadomość bądź cudzą wypowiedź. W kontekście „uczenia się, jak mieć prawo do miasta” wszystkie wypowiedzi są ważne; wskazują na poglądy cedynian o Cedyni i własne o współmieszkańcach; wypowiedzi pośrednio charakteryzują też autora pod względem chociażby tego, czy dyskutant odnosi dyskusje do artykułu, pod którym jest czat, czy raczej ma inny cel i chce pozostawić inny ślad, aniżeli odnieść się do tematu e-debaty. W subiektywnej opinii autorki niniejszego artykułu niektóre treści są konstruktywne i pouczające oraz zawierają konkretne wskazówki odnośnie do naruszenia ładu przestrzennego w mieście; jak teksty opublikowane 22 kwietnia 2017 r. pod tytułem „Wymieniono tablicę informacyjną na nową, próbując łączyć ogień z wodą” albo „Turysto, poczuć się możesz jak na... cmentarzu" (Cedynia bez...).

$\mathrm{W}$ innej gminie mieszkańcy stworzyli społecznościowe forum dyskusyjne; przedstawione tam materiały informacyjno-edukacyjne są otwarte dla wszystkich, natomiast dyskusja jest widoczna wyłącznie dla zalogowanych internautów 
(Społecznościowe forum...). Aktywność mieszkańców-internautów jest pozycjonowana, a nadana automatycznie ranga nobilituje aktywnego mieszkańca (Ranga...). Na tej stronie jednym z wiodących tematów jest technika perswazji jako sposobu wyrobienia wspólnego stanowiska (Techniki...). Jest ona opisana jako technika wywierania pożądanego wpływu na dane zjawisko społeczne (np. na ludzkie zachowania i świadomość), zmierzające do osiągnięcia określonego celu, jak: wypracowanie zasad i norm koniecznych do współfunkcjonowania w lokalnej społeczności czy w ogóle w społeczeństwie. Na tej stronie jest mowa o tym, że bycie członkiem społeczności jest równoznaczne $\mathrm{z}$ faktem bycia nakłanianym do dostosowania się do odgórnie narzuconych reguł i praw, i że wykroczenie poza ów obowiązujący kanon zwykle oznacza dotkliwe sankcje nie tylko o charakterze prawnym czy społecznym, lecz również efektów widocznych w najbliższej przestrzeni publicznej (Techniki...). Wypracowanie zasad i norm przez członków cedyńskiej społeczności w kontekście poszerzenia zasięgu ,własnego miejsca” i , własnego problemu” poza obręb domu i osobistego problemu oraz obejmowanie nimi publicznej przestrzeni, prawdopodobnie jest w stanie rozwiązać niektóre kwestie podniesione przez respondentów jako ważne problemy, wytypowane do rozwiązania przez program rewitalizacji w gminie (zanieczyszczone odchodami ulice, zagradzane dziedzińce i inne).

Można zaryzykować twierdzenie, że w kontekście omawianej problematyki (tożsamość transgranicznego miasta), analizowanej na podstawie danych zebranych $\mathrm{w}$ ramach partycypacyjnego programowania rewitalizacji, wypunktowane wyżej pozycje lokują źródło pochodzenia przyczyn obniżających jakość życia w Cedyni w sferze nie tylko stylu życia (kategoria subiektywna) mieszkańców i wszystkich interesariuszy, ale też warunków życia (kategoria obiektywna), jakie użytkownikom (klientom) zapewnia Cedynia jako instytucja miejska. Ważne jest zaznaczyć, że w miejscu styku tych dwóch kategorii powstaje trzecia kategoria - jakość życia w Cedyni, co w przypadku tego miasta jest znaczną podstawą utożsamienia się mieszkańców z miastem i wyrobienia tożsamościowego obrazu miejsca.

Analiza obiektywnie istniejącej infrastruktury w świetle wyników badań sondażowych ukazuje choć subiektywną, jednak nieprzekłamaną wartość obiektywnie istniejących warunków życia w mieście (potrzeba całodobowego komisariatu, wąskie chodniki, stan techniczny i estetyczny zabudowy, w tym zabytkowej). $\mathrm{PwC}^{13}$, badając „Kapitał jakości życia”, wykorzystywał w jego wyznaczaniu

${ }^{13}$ PwC jest nazwą handlową PricewaterhouseCoopers, globalnej sieci przedsiębiorstw świadczących usługi księgowe, audytorskie i doradcze; utworzona w 1998 r. w wyniku połączenia Price Waterhouse oraz Coopers\&Lybrand. 
miary o charakterze wskaźników obiektywnych - stan środowiska naturalnego, jakość usług medycznych, jakość usług edukacyjnych czy bezpieczeństwo (PwC, Jeran 2012). Niemniej, rosnącą złożoność kategorii jakości życia wyraża się coraz częściej zastępowaniem tego określenia takimi nazwami, jak: poczucie szczęścia, satysfakcja z życia, ogólne zadowolenie z życia, dobrostan (psychiczny lub psychologiczny) (Słaby 2011). „Przywołane synonimy wprost odwołują się do ocen i subiektywizmu, jednak w wielu badaniach łączy się podejście obiektywne i subiektywne, dociekając z jednej strony - poziomu zaspokojenia określonych potrzeb albo opisu warunków życia, z drugiej zaś - oceny owego stanu" (Jeran 2015, s. 223).

W celu wykrywania miary kapitału jakości życia w Cedyni poproszono respondentów o wskazanie atutów i słabych stron cedyńskiej przestrzeni postrzeganej z perspektywy obiektywnie występujących w nim elementów (tab. 1). Treść tabeli 1 uwzględnia opinie interesariuszy uzyskane zarówno za pomocą badań sondażowych, jak i podczas warsztatów i innych spotkań realizowanych przy partycypacyjnym programowaniu rewitalizacji (LPR 2017, załącznik 2). Jako atuty Cedyni wymieniano: ciekawą historyczną zabudowę, zabytki, rynek - miejsce wydarzeń i spotkań, ukształtowanie terenu, mozaiki na budynkach, fontannę z ławeczkami, aleje kasztanową, liczbę punktów handlowo-usługowych i tereny zielone. Lista słabych stron była dłuższa. Jako kluczowy problem Cedyni została wskazana niedostateczna aktywność społeczna samych mieszkańców, w szczególności w zakresie inicjatyw lokalnych. Niski stopień przedsiębiorczości, w pewnym sensie, stanowi wypadkowe stylu życia i chęci bycia aktywnym na rzecz lokalnej społeczności. Słabością jest także niekorzystny, w opinii mieszkańców, odbiór Cedyni przez osoby zewnątrz i zewnętrzne instytucje. Przyczynę takiej opinii respondenci widzą w zniszczonych elewacjach kamienic, zagraconych podwórkach, złym stanie technicznym ulic i chodników. Na niską ocenę jakości życia w mieście wpływają również niezagospodarowane obszary zielone i niewystarczająca oferta spędzania wolnego czasu, co w opinii ankietowanych stanowi kolejny problem wymagający pilnej interwencji.

Respondenci stali na stanowisku, że należy „ożywić” rynek, przywrócić jego dawne, społeczne funkcje; twierdzili, że kiedyś rynek był sercem i prawdziwym centrum miasta. Mieszkańcom Cedyni brakuje kina, które do niedawna było na rynku (uległo zniszczeniu w pożarze, na jego miejscu jest obecnie parking) i stanowiło ogniwo życia towarzyskiego mieszkańców. W opinii mieszkańców cedyński rynek jest nieuporządkowany, a elewacje niektórych budynków są tak zdewastowane, że obniżają nie tylko estetyczną wartość miejsca, ale wręcz odbierają chęć przebywania na rynku. (Brak infrastruktury zachęcającej do inte- 
gracji przyczynił się do zainaugurowania akcji „zróbmy coś razem” i zorganizowania przez mieszkańców wspomnianej wcześniej kawiarenki sąsiedzkiej w bezpośrednim sąsiedztwie rynku).

Tabela 1. Zasoby kapitału jakości życia w Cedyni na podstawie ustnych i pisemnych wypowiedzi cedyńskich interesariuszy

\begin{tabular}{|c|c|c|}
\hline Atuty Cedyni & Słabości Cedyni & $\begin{array}{c}\text { Obiekty wytypowane } \\
\text { do rewitalizacji }\end{array}$ \\
\hline $\begin{array}{l}\text { Ciekawa historyczna } \\
\text { zabudowa i zabytki } \\
\text { Ukształtowanie terenu } \\
\text { (Cedynia na wzgórzach) } \\
\text { Mozaiki na budynkach } \\
\text { Fontanna z ławeczkami } \\
\text { Aleja kasztanowa } \\
\text { Koncentracja punktów } \\
\text { handlowo-usługowych } \\
\text { Rynek jako miejsce } \\
\text { wydarzeń i spotkań } \\
\text { Tereny zielone } \\
\text { 41 projektów złożonych } \\
\text { do rozwiązywania } \\
\text { kluczowych problemów } \\
\text { w mieście (LPR 2017, } \\
\text { s. 121-180) } \\
\text { Młodzi cedynianie, którzy } \\
\text { wyjechali z miasta, piszą } \\
\text { prace na jej temat } \\
\text { Zwolnione tempo życia }\end{array}$ & $\begin{array}{l}\text { Słaba aktywność mieszkańców } \\
\text { (inicjatywy społeczne) } \\
\text { Zaniedbane kamienice } \\
\text { Zagracone podwórka } \\
\text { Zaniedbany ośrodek } \\
\text { rekreacyjno-sportowy } \\
\text { Niekorzystna struktura } \\
\text { demograficzna (dominacja } \\
\text { osób starszych i mało dzieci) } \\
\text { Zaniedbany teren po byłym } \\
\text { PGR } \\
\text { Brak centrum kultury (domu } \\
\text { kultury z pełną infrastrukturą) } \\
\text { Bariery architektoniczne } \\
\text { (niepełnosprawni, rodzice } \\
\text { z wózkami) } \\
\text { Słaba oferta aktywnego } \\
\text { spędzania czasu dla różnych } \\
\text { grup wiekowych } \\
\text { Zły stan budynku szkoły } \\
\text { Zły stan budynku ośrodka } \\
\text { zdrowia } \\
\text { Niezagospodarowane tereny } \\
\text { zielone } \\
\text { Brak całodobowego } \\
\text { komisariatu policji } \\
\text { Dysfunkcje społeczne } \\
\text { Zanieczyszczony teren wokół } \\
\text { budynków (psie odchody) } \\
\text { Zły stan nawierzchni ulic } \\
\text { Wąskie chodniki }\end{array}$ & $\begin{array}{l}\text { Wieża widokowa i teren } \\
\text { wokół } \\
\text { Kirkut } \\
\text { Budynek szkoły wraz } \\
\text { z otoczeniem } \\
\text { Ośrodek rekreacyjno- } \\
\text {-sportowy } \\
\text { Piwnice po PGR } \\
\text { Kwartał zabytkowy } \\
\text { w północnej części miasta } \\
\text { Teren po byłym kinie } \\
\text { Teren wokół COKiS } \\
\text { Ulica Krótka } \\
\text { Remont kamienic przy } \\
\text { placu Wolności } \\
\text { Aleja kasztanowa } \\
\text { Grodzisko } \\
\text { Budowa budynku } \\
\text { komunalnego } \\
\text { czynszowego } \\
\text { Rozbudowa przychodni } \\
\text { zdrowia }\end{array}$ \\
\hline
\end{tabular}

Źródło: LPR 2017. 
Respondenci widzą również problem małej architektury, która jest w złym stanie technicznym i dewastowana mimo cyklicznego ich naprawiania. W mieście jest dostateczna liczba obiektów infrastruktury sportowo-rekreacyjnej, ale nie są one wykorzystane, co również znalazło odzwierciedlenie w wypowiedziach mieszkańców. Respondenci mają świadomość, że nie brakuje w mieście problemów środowiskowych. Rzeczywiście miejscowość nie została do tej pory zgazyfikowana i nie posiada sieci centralnego ogrzewania.

Cedynianie zidentyfikowali obiekty/tereny, które wymagają pilnej rewitalizacji. Jest to: wieża widokowa $\mathrm{z}$ terenami przyległymi, łącznie $\mathrm{z}$ pozostałością kirkutu, budynek szkoły, ośrodek rekreacyjno-sportowy, piwnice, kwartał zabytkowy w północnej części Cedyni, teren po byłym kinie, teren wokół Cedyńskiego Ośrodka Kultury i Sportu (COKiS) wraz z ulicą Krótką, kamienice przy placu Wolności, aleja kasztanowa i grodzisko. Większość z nich została opisana $\mathrm{w}$ artykule. Wszystkie wytypowane do rewitalizacji miejsca powstały w okresie przedwojennym.

\section{Podsumowanie}

Koncepcja morfoznaku, za pomocą techniki dekompozycji tkanki miejskiej do jej niepodzielnych składowych (ulice, place, budowle, zieleń, ich cechy według kodu obrazowego i semantycznego) poszukuje tożsamości dzisiejszej Cedyni, gdzie z wyjątkiem piastowskiej pamięci, prawie nic nie odwołuje się do kulturowych korzeni obecnych mieszkańców (patrz: Rybarska-Jarosz, Barylski 2012 , s. $68,71,89)$. W okresie powojennym powstały pewne budowle i kompleksy, jednak autorka uważa, są to przykłady kultury minionego, komunistycznego okresu w Polsce (np. kompleks PGR), a nie polskiej kultury. Aczkolwiek cedynianie są dumni z trzech mozaik. Przyczyną prawdopodobnie jest tematyka lub również ich wartość artystyczna. Niezależnie od impulsu, jest to coś, z czym cedynianie chcą się pochwalić.

Cedynię naznaczają pozytywne cechy, które świadczą o jej tożsamości a które nie zostały omówione $\mathrm{w}$ artykule $\mathrm{z}$ braku miejsca, oraz walory miejsca, które nie poddają się opisowi, np. cisza i spokój, będące niebagatelnym atutem. „Cedynia nie pędzi w czasie", przez co słyszalny jest tam rytm czy dźwięk przyrody. Możliwie, że w najbliższej przyszłości, przy założeniu, że infrastrukturalne i estetyczne niedociągnięcia będą minimalizowane, miasto ma szansę stać się „azylem ciszy” w zasięgu wielkich europejskich metropolii. Mimo występowania w mieście negatywnych zjawisk, miasto charakteryzuje się niemałym potencjałem wewnętrznym (zwłaszcza historycznym, przyrodniczym, kulturowym) 
i posiada istotne znaczenie dla rozwoju społeczno-gospodarczego całej gminy oraz obszarów transgranicznych (tab. 1).

Konsensus między „prawem do miasta” i ,prawami miasta”, co zdecydowanie wpłynie na tożsamość Cedyni - miasta odnowionego przez obecnych mieszkańców - do pewnego stopnia reguluje Ustawa o rewitalizacji (2015) dzięki zdefiniowaniu pojęć interesariuszy i partycypacji społecznej. Przekazuje ona do rąk mieszkańców, organizacji pozarządowych, osób prywatnych, podmiotów publicznych i innych organizacji, narzędzie planistyczne, za pomocą którego włączeni do procesu partycypacyjnego programowania cedynianie mogą przekształcać swoje miasto (tab. 1), znajdując optymalne (z perspektywy publicznej przestrzeni, a nie interesów pojedynczych interesariuszy) rozwiązanie poprzez programowanie odnowy wynikającej z kompromisu między członkami lokalnej społeczności (konsensus na poziomie mieszkaniec-mieszkaniec) oraz posiadanymi zasobami i proponowanymi propozycjami (konsensus na poziomie miasto-mieszkaniec). Jeśli obecni mieszkańcy będą widzieć w jutrzejszej Cedyni owoc składanych przez siebie propozycji, to ten akt sam w sobie zawiera bodziec utożsamiania się z miejscem.

Poszukując ducha miejsca, z którym mieszkańcy identyfikują się kulturowo, poza miejscem bitwy pod Cedynią, grodziskiem i trzema mozaikami, należy zaznaczyć obecnie powstające miejsca, z którymi, być może, w przyszłości mieszkańcy będą się utożsamiać, bo sami je stworzyli albo uporządkowali, lub dlatego, że sami je wytypowali do programu rewitalizacji (tab. 1). Wzorem opracowania o dylematach regionalnej tożsamości Górnego Śląska (Szczepański, Śliz 2010), tożsamość Cedyni i i jej mieszkańców jest poczuciem uświadomionej lub podświadomej przynależności społeczności lokalnej do miejsca, w którym żyją. Podczas rozmów prowadzonych na spotkaniach z mieszkańcami, wiele osób zaznaczało, że ,rodzice przyjechali, ale oni i ich dzieci już tu się urodzili”. Oznacza to, że pojawia się poczucie zasiedziałości, co jest bardzo ważnym bodźcem utożsamiania się z miejscem. W odróżnieniu od mieszkańców Górnego Śląska, prawdopodobnie brakuje u cedynian poczucia odrębności kulturowej. Jest natomiast zbiorowa identyfikacja (świadomość piastowskiej przeszłości) w stosunku do nielicznych znaków (symboli materialnych, zwyczajów, zachowań) oraz pojawia się odczuwanie przeszłości i teraźniejszości Cedyni. Czy cechy te będą wzmacniane, pozostaną na obecnym poziomie czy zanikną zależy $\mathrm{w}$ dużej mierze od unaocznienia $\mathrm{w}$ przestrzeni miejskiej materialnych efektów złożonych przez interesariuszy propozycji. 


\section{Literatura}

Benedict R., 1966, Wzory kultury, Warszawa.

Białecki T. (red.), 2002, Słownik współczesnych nazw geograficznych Pomorza Zachodniego z nazwami przejściowymi z lat 1945-1948, Szczecin.

Brzostek B., 2009, PRL: propaganda czy polityka historyczna? [w:] Skibiński P., Wiścicki T. (red.), Polityka czy propaganda. PRL wobec historii, Warszawa, s. 57-86.

Bullarium Poloniae, 1982, t. 1, Romae.

Conzen M.R.G., 1960, Alnwick, Northumberland: a study in town-plan analysis, London.

Dzwonkowski W., 1918, Prahistorja ziem polskich. Słowiańszczyzna pierwotna. Początki polskiej kultury i organizacji, Warszawa.

Gordon M.M., 1947, The concept of the sub-cultur and its application, „Social Forces”, 26 (1), s. 40-42.

Górski A.S., 2016, Znaczenie partycypacji społecznej $w$ procesie rewitalizacji, „Prace Naukowe Uniwersytetu Ekonomicznego we Wrocławiu. Gospodarka przestrzenna XXI wieku", 443, s. 89-94.

Gut P., 2013, Z dziejów ustrojowych Cedyni w XVIII w., [w:] Migdalski P. (red.), Cedynia i okolice poprzez wieki, Chojna-Szczecin, s. 163-170.

Gut P., 2014, Z dziejów społecznych i gospodarczych Cedyni w XVIII w., [w:] Migdalski P. (red.), Civitas Cedene. Studia i materiaty do dziejów Cedyni, t. 1. Chojna-Szczecin -Cedynia, s. 165-173.

Hall E.T., 1959, The silent language, New York.

Hall E.T., 1987, Bezgłośny język, Warszawa.

Harvey D., 1982, Limits to capital, Londyn.

Harvey D., 2012, Bunt miast. Prawo do miasta i miejska rewolucja, Warszawa.

Jasiński A., 2010, O wielokulturowych aspektach współczesnej przestrzeni publicznej, „Architektura”, 2-A (5), s. 171-179.

Jeran A., 2012, Jakość życia w Bydgoszczy - refleksje nad dwoma raportami, [w:] Sawaniewska-Moch Z., Moch W. (red.), Krajobraz społeczno-kulturowy województwa kujawsko-pomorskiego na tle innych regionów Polski, Bydgoszcz.

Jeran A., 2015, Jakość $i$ warunki życia - perspektywa mieszkańców i statystyk opisujacych miasta na przykładzie Bydgoszczy, Torunia $i$ Włocławka, „Roczniki Ekonomiczne Kujawsko-Pomorskiej Szkoły Wyższej w Bydgoszczy”, 8, s. 222-235.

Kiernikiewicz-Wieczorkiewicz J., 1997, Miasto - przestrzeń wspólnego dobra, [w:] Materiały II Sympozjum Teoria i Praktyka Rozwoju Przestrzeni Miejskiej, Gliwice, s. 51-55.

Kłoczowski J., 1998, Europa Środkowo-Wschodnia w kręgu cywilizacji chrześcijańskiej średniowiecza, Lublin.

Kociuba J., 2012, Pomorze. Praktyczny przewodnik turystyczny po ziemiach dawnego Księstwa Pomorskiego, Szczecin.

Kościelna J.A., 2014, Obraz Cedyni w pracach Johanna Christopha Beckmanna (1641 -1717), [w:] Migdalski P. (red.), Civitas Cedene. Studia i materiaty do dziejów Cedyni, t. 1. Chojna-Szczecin-Cedynia, s. 153-163. 
Koter M., 1974, Fizjonomia, morfologia i morfogeneza miasta. Przeglad rozwoju oraz próba uściślenia pojęć, „Zeszyty Naukowe Uniwersytetu Łódzkiego. Nauki Matematyczno-Przyrodnicze", II, 55, Łódź.

Larkham P., 1991, A glossary of urban form, Birmingham.

Lefebvre H., 2009, Le droit à la ville, Paryż.

Lewandowski J., Goleman W., 1999, Samoidentyfikacja mniejszości narodowych i religijnych w Europie Środkowo-Wschodniej, Lublin.

Marcuse P., 2013, Rights in cities and the right to the city?, [w:] Sugranyes A., Mathivet Ch. (red.), Cities for all: proposals and experiences to-wards the right to the city: http://publica.pl/teksty/prawa-w-miastach-a-prawo-do-miasta-36626.html (01.06.2016).

Migdalski P., 2007, ...w tej strażnicy Rzeczypospolitej. Rejon Pamięci Narodowej Cedynia-Gozdowice-Siekierki, Szczecin.

Morawska J., 2015, Losy polskich osadników, „Gazeta Chojeńska”, 18 (1087) z dnia 05.05.2015.

Olejnik K., 1988, Cedynia, Niemcza, Głogów, Krzyszków, Kraków.

Polniak Ł., 2011, Patriotyzm wojskowy w PRL w latach 1956-1970, Warszawa.

Pirveli M., 2011, Od morfologii przez urbomorfologię do morfoznaku, „Przegląd Geograficzny”, 83 (4), s. 507-529.

Rajman J., 2009, Grody kasztelańskie a średniowieczne miasta (z genezy pomorskich miast), „Słupskie Prace Geograficzne”, 6, s. 5-18.

Rykiel Z., Pirveli M., 2005, Środowisko przyrodnicze a środowisko geograficzne; ujęcie krytyczne, [w:] Maik W., Rembowska K., Suliborski A. (red.), Geografia jako nauka o przestrzeni, środowisku i krajobrazie. Podstawowe idee i koncepcje $w$ geografii, t. 1, Łódź-Toruń, s. 130-147.

Rykiel Z., Pirveli M., 2009, Przestrzeń miasta a duch miejsca-przykład Rzeszowa, [w:] Styk J. (red.), Przestrzeń antropogeniczna miasta Lublina: waloryzacja, wytwarzanie, użytkowanie. Część pierwsza materiatów z konferencji, Lublin, s.177-191.

Rymar E., 2013, Cedynia jako ośrodek administracyjny (XII-XIII w.) i miejski (XIII -XVI w.), [w:] Migdalski P. (red.), Cedynia i okolice poprzez wieki, Chojna-Szczecin, s. $113-126$.

Schmook R., 2013, Cedynia w latach 1871-1933, [w:] Migdalski P. (red.), Cedynia i okolice poprzez wieki, Chojna-Szczecin, s. 205-217.

Sieradzki P., 2011, Rola teorii socjologicznych $w$ rozumieniu $i$ wyjaśnianiu zjawisk społecznych, „Kultura i Wychowanie”, 2, s. 135-145.

Słaby T., 2011, Nowe propozycje w badaniach jakości życia, „Studia i Prace Kolegium Zarządzania i Finansów", 108, s. 125-136.

Szczepański M. S., Śliz A., 2010, Dylematy regionalnej tożsamości. Przypadek Górnego Śląska, „Nowe Zagłębie” 6 (12), s. 17-20.

Szücs J., 1995, Trzy Europy, Lublin.

Tönnies F., 1988, Wspólnota i stowarzyszenie, Warszawa. 
Tönnies F., 1975, Wspólnota i społeczeństwo, [w:] Derczyński W., Jasińska-Kania A., Szacki J. (red.), Elementy teorii socjologicznych, Warszawa, s. 46-66.

Wołągiewicz R., 1960, Osada i grób z okresu rzymskiego w Cedyni nad Odra, ,Materiały Zachodnio-Pomorskie", 6, s. 97-158.

Zblewski Z., 2001, Leksykon PRL-u, Kraków.

Znaniecki F., 1912, Humanizm i poznanie, Warszawa.

Znaniecki F., 1919, Culturaly reality, Chicago.

Znaniecki F., 1938, Socjologiczne podstawy ekologii ludzkiej, „Ruch Prawniczy, Ekonomiczny i Socjologiczny", 1, s. 89-119.

Zaremba M., 2005, Komunizm, legitymizacja, nacjonalizm. Nacjonalistyczna legitymizacja władzy komunistycznej w Polsce, Warszawa.

\section{Dokumenty i źródla internetowe (dostęp: IX.2017)}

Antykwariat Sobieski https://antyksobieski.pl/merian-prospect-dess-ambts-zehden-cedy nia-panorama-cedyni-1652r.html

Cedynia bez cenzury: http://cedyniabezcenzury.pl/

Cedynia.fotopolska.eu: http://cedynia.fotopolska.eu/Cedynia

Cedynia.pl: http://cedynia.pl/rewitalizacja

Cmentarz żydowski: www.kirkuty.xip.pl/cedynia.htm

Konkurs „Kwiatami Cedynię upiększamy”: http://www.cedynia.pl/um/750-kwiatamicedynie-upiekszamy-2

Korzeń J., 2009, Studium uwarunkowań i kierunków zagospodarowania przestrzennego miasta i gminy Cedynia, Cedynia.

LPR 2017, Lokalny Program Rewitalizacji Gminy Cedynia na lata 2017-2023: http://bip.cedynia.pl/Article/get/id,21799.html

Obserwatorium żywej kultury - sieć badawcza: http://ozkultura.pl/wpisy/86

Piątek C., 2017, Tak powstała letnia kawiarenka sąsiedzka. Cedynia bez cenzury: http://cedyniabezcenzury.pl/joomla_nowa/index.php/1349-tak-powsta\%C5\%82aletnia-kawiarenka-s\%C4\%85siedzka.html

Program usuwania azbestu i wyrobów zawierających azbest z terenu Gminy Cedynia: http://bip.cedynia.pl/Article/get/id,16364.html

PwC, Raporty na temat wielkich miast Polski, Bydgoszcz: http://www.pwc.com/pl

Ranga. Społecznościowe forum dyskusyjne mieszkańców Klimontowa i gminy: http://www.tpk.fora.pl/regulamin-forum-dyskusyjnego-uwaga-w-okresie-1-viii-200831-i-2009-forum-bylo-zawieszone,34/jak-uzyskiwac-kolejne-wyzsze-rangi-naforum, 784.html\#6698

Rozporządzenie Ministrów: Administracji Publicznej i Ziem Odzyskanych z dnia 12 listopada 1946 r., M.P. 1946 nr 142 poz. 262.

Rybarska-Jarosz D., Barylski L., 2012, Tożsamość regionalna mieszkańców województwa zachodniopomorskiego. Raport z badań eksploracyjno-diagnostycznych, ZAPOL, Szczecin: http://ois.wzp.pl/attachments/article/103/tozsamosc_z_aneks.pdf

Serwis Nauka w Polsce: www.naukawpolsce.pap.pl (http://naukawpolsce.pap.pl/ aktualnosci/news,405439,cedynia-w-czasie-i-przestrzeni--konferencja-popularnonau kowa.html) 
Społecznościowe forum dyskusyjne mieszkańców Klimontowa i gminy: http://www. tpk.fora.pl/

Studium Uwarunkowań i Kierunków Zagospodarowania Przestrzennego Gminy Cedynia. Zmiana 2017. Załącznik Nr 2 do uchwały Rady Miejskiej w Cedyni z 2017 r. w sprawie uchwalenia zmiany studium uwarunkowań i kierunków zagospodarowania przestrzennego Gminy Cedynia.

Śleszyński P., Bednarek-Szczepańska M., Górczyńska M., Korcelli-Olejniczak E., 2016, Komentarz do Ustawy o rewitalizacji z dnia 09 października 2015 r. Problemy Rozwoju Miast. Ministerstwo Infrastruktury i Budownictwa Departament Polityki Przestrzennej, Warszawa.

Techniki. Społecznościowe forum dyskusyjne mieszkańców Klimontowa i gminy: www.tpk.fora.pl/najblizsze-wybory-do-rady-gminy-i-na-funkcje-wojta-burmistrza,32 /techniki-sterowania-ludzmi,338.html

Urban studies... UiO, University of Oslo, Department of Sociology and Human Geography: //www.sv.uio.no/iss/english/research/subjects/urban-studies/

Ustawa z dnia 9 października 2015 r. o rewitalizacji. Dz.U. z 2015 r., poz. 1777: http://isap.sejm.gov.pl/DetailsServlet?id=WDU20150001777

UW - Barbara Fatyga www.kultura-regionow.pl/2,41,Barbara_Fatyga.htm

\section{The concept of morphosign with image and semantic code in studies of cross-border town's identity on the example of Cedynia}

\section{Summary}

The article is theoretical and empirical in character. It discusses the identity of the crossborder town and its inhabitants. The empirical material is a small part of the research performed for the revitalisation project. The author is sharing the thesis on the interplay of spatial and social structures; her assumption is that, without knowing the content of the past of a place, the genius loci, it remains an empty place. The text consists of 6 parts. The first is an introduction containing an explanation of the most important terms, followed by a detailed description of the area of research, urban tissue, the definition and pattern of the morphosign. Section 5 partially summarizes results of the public consultation and is followed by a summary.

Keywords: urban tissue, community, Cedynia, the right to the city, morphosign.

Marika Pirveli, dr Uniwersytet Szczeciński, Wydział Nauk o Ziemi ul. Mickiewicza 18, 70-383 Szczecin e-mail: mariam.pirveli@usz.edu.pl 